\title{
Stability and biological activity of $E$. coli derived soluble and precipitated bone morphogenetic protein-2
}

Bastian Quaas $^{\mathrm{a}}$, Laura Burmeister ${ }^{\mathrm{b}, \mathrm{c}}$, Zhaopeng $\mathrm{Li}^{\mathrm{a}}$, Alexandra Satalov ${ }^{\mathrm{d}, \mathrm{e}}$, Peter Behrens ${ }^{\mathrm{c}, \mathrm{d}}$, Andrea Hoffmann $^{\mathrm{b}, \mathrm{c}}$, Ursula Rinas ${ }^{\star a, f}$

${ }^{a}$ Leibniz University of Hannover, Technical Chemistry - Life Science, Hannover, Germany

b Hannover Medical School, Department of Orthopedic Surgery, Graded Implants and Regenerative Strategies, Laboratory of Biomechanics and Biomaterials, Hannover, Germany

c Lower Saxony Center for Biomedical Engineering, Implant Research and Development, Hannover, Germany

${ }^{\mathrm{d}}$ Leibniz University Hannover, Institute for Inorganic Chemistry, Germany

${ }^{\text {e }}$ current address: Pasargad Institute for Advanced Innovative Solutions, Tehran, Iran

f Helmholtz Centre for Infection Research, Braunschweig, Germany

${ }^{*}$ Corresponding author:

Helmholtz Centre for Infection Research, Inhoffenstraße 7, D-38124, Braunschweig,

Germany. Tel: + 495316181 7014, Fax: + 495316181 7099, Email:

Ursula.Rinas@helmholtz-hzi.de 


\section{ABSTRACT}

Purpose: There is a plethora of studies on recombinant human bone morphogenetic protein2 (rhBMP-2) application and delivery systems, but surprisingly few reports address the biophysical properties of the protein which are of crucial importance to develop effective delivery systems or to solve general problems related to rhBMP-2 production, purification, analysis and application.

Methods: The solubility, stability and bioactivity of rhBMP-2 obtained by renaturation of $E$. coli derived inclusion bodies was assessed at different $\mathrm{pH}$ and in different buffer systems using (dynamic) light scattering and thermal shift assays as well as intrinsic fluorescence measurements and luciferase based bioassays.

Results: rhBMP-2 is poorly soluble at physiological $\mathrm{pH}$ and higher. The presence of divalent anions further decreases the solubility even under acidic conditions. Thermal stability analyses revealed that rhBMP-2 precipitates are more stable compared to the soluble protein. Moreover, correctly folded rhBMP-2 is also bioactive as precipitated protein and precipitates readily dissolve under appropriate buffer conditions. Once properly formed rhBMP-2 also retains biological activity after temporary exposure to high concentrations of chaotropic denaturants. However, care should be taken to discriminate bioactive rhBMP-2 precipitates from misfolded rhBMP-2 aggregates, e.g. resolvability in MES buffer (pH 5) and a discrete peak in thermoshift experiments are mandatory for correctly folded rhBMP-2.

Conclusions: Our analysis revealed that E. coli derived rhBMP-2 precipitates are not only bioactive but are also more stable compared to the soluble dimeric molecules. Knowledge about these unusual properties will be helpful to design improved delivery systems requiring lower amounts of rhBMP-2 in clinical applications.

\section{Keywords:}

protein aggregation; protein solubility; protein stability; refolding; recombinant human bone morphogenetic protein-2 


\section{Introduction}

Bone morphogenetic protein-2 (BMP-2) is a member of the transforming growth factor- $\beta$ (TGF- $\beta$ ) family [1]. It is a disulfide-connected, homodimeric cystine-knot protein (114 residues per monomer, isoelectric point: $\mathrm{p} /$ 8.5) well known for its ectopic bone inducing capacities [1-3]. Most importantly, the osteogenic properties of rhBMP-2 are exploited in clinical applications which range from bone fracture healing to spinal fusions [4,5]. For example, implants using adsorbable collagen sponges as carriers for rhBMP-2 are used for treatment of spinal fusions, bone defects, internal fixation of fractures and reconstitution of maxillofacial conditions [4]. The amount of rhBMP-2 employed in these implants (6-12 mg total dose, [6]) exceeds the natural concentration more than 10.000 times (1-2 $\mu \mathrm{g}$ per $\mathrm{kg}$ of bone, [7]) leading to high costs and enhanced risks of critical side effects. Side effects mainly related to these high doses comprise ectopic bone formation at unwanted sides, osteolysis, postoperative radiculitis, nerve root compression and others [6]. Current implants are based on rhBMP-2 produced by recombinant DNA technology using Chinese hamster ovary cells $(\mathrm{CHO})[8]$.

Production of rhBMP-2 through refolding of $E$. coli based inclusion bodies has been developed long ago as a viable alternative and a more economic source for biologically active rhBMP-2, e.g. $[9,10]$. Interestingly, E. coli derived rhBMP-2 induces ectopic bone formation at lower concentrations compared to the cell culture derived protein, maybe due to the lack of glycosylation [11]. Currently, E. coli derived rhBMP-2 is mainly used in research and development such as tissue engineering related areas as well as an ingredient for cell culture media for osteogenic induction of appropriate cell types [12,13].

There is a plethora of studies on rhBMP-2 application and delivery systems, but surprisingly few reports address the biophysical properties of the protein which are of crucial importance to develop effective delivery systems or to solve general problems related to rhBMP-2 production, purification, analysis and application. Most studies on rhBMP-2 properties are 
related to the stability of $\mathrm{CHO}$ cell derived rhBMP-2, e.g. analyzing the stability in formulations and searching for manufacturer-dependent differences of protein properties [14] or analyzing properties of salt-induced rhBMP-2 precipitates for developing novel formulation methods $[15,16]$. Bone-derived glycosylated BMP-2 is a very thermostable protein when disulfide bonds are properly formed $[7,17]$. However, the glycosylated $\mathrm{CHO}$ cell derived protein also possesses a high aggregation propensity forming aggregates/precipitates at neutral to higher $\mathrm{pH}[14,18]$ and also exhibits an unusual solubility in the presence of salts [19]. On the other hand, it has been shown that salt-induced $\mathrm{CHO}$ cell derived rhBMP-2 precipitates retain their bioactivity and structural integrity $[15,16]$ and the glycosylated $\mathrm{CHO}$ cell derived protein remains bioactive even upon storage in dry state [20].

The $E$. coli derived non-glycosylated rhBMP-2 is also a very thermostable protein surviving 2 $\mathrm{h}$ at $70^{\circ} \mathrm{C}$ without loss of bioactivity [21] but forms aggregates when exposed to a $\mathrm{pH}$ above $\mathrm{pH} 6$ [22]. So far efforts have been undertaken to prevent formation of rhBMP-2 aggregates/precipitates but studies on their properties are yet missing. Here, we present a detailed analysis of the properties of E. coli-derived rhBMP-2 regarding solubility, thermal stability and bioactivity in different buffer systems. Moreover, we also present a comprehensive study on the resolvability, thermal stability and bioactivity of $E$. coli-derived rhBMP-2 aggregates/precipitates. 


\section{Material and methods}

\section{Production, refolding and purification of non-glycosylated rhBMP-2}

Non-glycosylated rhBMP-2 was obtained by refolding from E. coli BL21(DE3):pET29crhBMP-2 derived inclusion bodies (IBs) and subsequent purification as described previously $[9,10,23]$. Briefly, solubilization of $1 \mathrm{~g}$ of wet rhBMP-2 IBs in $15 \mathrm{ml} 6 \mathrm{M}$ guanidine-HCl (GdnHCl), 100 mM DTT, 5 mM EDTA, 100 mM tris(hydroxymethyl)aminomethane (TRIS, pH 8.5) was carried out overnight. The solubilization mixture was cleared from aggregates by centrifugation at $16.000 \times \mathrm{g}$ for $30 \mathrm{~min}$. The resulting supernatant was subjected to refolding which was carried out for 7 days by dilution of $5 \mathrm{ml}$ of solubilized rhBMP-2 into $250 \mathrm{ml}$ of 500 mM Gdn-HCl, 750 mM N-cyclohexyl-2-aminoethanesulfonic acid (CHES), 5 mM EDTA, 2 $\mathrm{mM}$ reduced glutathione, $1 \mathrm{mM}$ oxidized glutathione, $50 \mathrm{mM}$ TRIS $(\mathrm{pH} 8.5)$ at $10^{\circ} \mathrm{C}$. Afterwards, the refolding mixture was centrifuged at $16.000 \times \mathrm{g}$ for $30 \mathrm{~min}$ to clarify the solution from misfolded rhBMP-2 aggregates. Prior to Heparin chromatography the clarified supernatant was mixed (1:1) with $8 \mathrm{M}$ urea and filtered using a $0.2 \mu \mathrm{m}$ polyethersulfone (PES) sterile filter (Sartorius, Germany). The rhBMP-2 containing filtrate was applied to a HiPrep Heparin FF 16/10 column (GE Healthcare, USA) equilibrated with 5 column volumes (CV) equilibration buffer (4 M urea, $20 \mathrm{mM}$ TRIS, pH 8) using an ÄKTA Pure system (GE Healthcare, USA). Subsequently, the column was washed with $5 \mathrm{CV}$ equilibration buffer. An isocratic elution was used to separate monomeric and dimeric rhBMP-2. The first elution step was done with a buffer containing $320 \mathrm{mM} \mathrm{NaCl}, 4 \mathrm{M}$ urea, $20 \mathrm{mM}$ TRIS (pH 8) for $5 \mathrm{CV}$. The second elution step was performed using the same buffer with $420 \mathrm{mM} \mathrm{NaCl}$. The fractions were analyzed by SDS-PAGE and those containing only dimeric rhBMP-2 were merged. The fractions containing rhBMP-2 dimer were dialyzed using a Zellutrans membrane with a cut-off of 6,000-8,000 MWCO (Carl Roth, Germany). The dialysis was carried out against 50 mM 2( $\mathrm{N}$-morpholino)ethanesulfonic acid (MES, pH 5) for about 16 hours (1:500 v/v) followed by another dialysis using the same buffer and volume for additional 24 hours. The final refolded 
and purified rhBMP-2 dimer containing dialysate was filtered using a $0.22 \mu \mathrm{m}$ PES sterile filter (Sartorius, Germany), the filtrate stored at $-80^{\circ} \mathrm{C}$ and used for subsequent analysis.

Analysis of solubility and quantification of soluble and precipitated rhBMP-2 in different buffers

rhBMP-2 in 50 mM MES (pH 5) was concentrated by ultrafiltration (10 kDa cut off Amicon, Merck Millipore, USA), the solution filtered using a $0.45 \mu \mathrm{m}$ PES filter (Wicom, Heppenheim, Germany) and the final concentration of rhBMP-2 in the filtrate adjusted to $500 \mu \mathrm{g} / \mathrm{ml}$ with 50 $\mathrm{mM}$ MES $(\mathrm{pH} 5)$. The concentration of rhBMP-2 in this stock solution was determined using an extinction coefficient of $18825 \mathrm{M}^{-1} \mathrm{~cm}^{-1}$ at $280 \mathrm{~nm}$ (NanoDrop 1000, Thermo Fisher, USA). This rhBMP-2 stock solution was diluted 1:20 into different buffers (all $50 \mathrm{mM}$ in concentration, $\mathrm{pH}$ adjustment with aqueous $\mathrm{HCl}$ or $\mathrm{NaOH})$ including citrate $(\mathrm{pH} 2$ [2.01], $\mathrm{pH}$ 2.5 [2.77] and pH 3 [3.08]), oxalate (pH 2.5 [2.58], $\mathrm{pH} 3$ [3.07], $\mathrm{pH} 3.5$ [3.04], $\mathrm{pH} 4$ [4.01], pH 4.5 [4.50] and $\mathrm{pH} 5$ [4.96]), acetate (pH 3.5 [3.59], $\mathrm{pH} 4$ [4.1], $\mathrm{pH} 4.5$ [4.45] and $\mathrm{pH} 5$ [4.95]), malonate $(\mathrm{pH} 2.5$ [2.52], $\mathrm{pH} 3$ [3.01], $\mathrm{pH} 3.5$ [3.56], $\mathrm{pH} 4$ [4.08], $\mathrm{pH} 4.5$ [4.57] and $\mathrm{pH} 5$ [5.05]), MES (pH 5 [5.13], pH 5.5 [5.59], pH 6 [6.03], pH 6.5 [6.45] and pH 7 [6.96]), 3-(Nmorpholino)propanesulfonic acid (MOPS, pH 6 [6.19], $\mathrm{pH} 6.5$ [6.56], $\mathrm{pH} 7$ [6.96] and pH 7.5 [7.45]), phosphate ( $\mathrm{pH} 6$ [6.08], $\mathrm{pH} 6.5$ [6.46], $\mathrm{pH} 7$ [6.9] and $\mathrm{pH} 7.5$ [7.39]), TRIS (pH 7.5 [7.42], pH 8 [8.17], pH 8.5 [8.79] and pH 9 [9.09]), CHES (pH 9 [9.09], pH 9.5 [9.56] and pH 10 [10.08]), and N-cyclohexyl-3-aminopropanesulfonic acid (CAPS, pH 10.5 [10.63] and pH 11 [11.15]) buffers and incubated at $8^{\circ} \mathrm{C}$ overnight. The measured $\mathrm{pH}$ after dilution is given in square brackets (data points in the figures correspond to the measured $\mathrm{pH}$ after dilution). Samples were homogenized by vortexing for 1 - 2 seconds (MS2, IKA, Germany) at mid speed $(1400 \mathrm{rpm})$ before aliquots were taken and the protein concentration (soluble and precipitated rhBMP-2) determined by an adapted sensitive Bradford assay [24]. Some delicate proteins can denature upon vortexing. However, vortexing has been also used to prepare $\mathrm{CHO}$ cell derived rBMP-2 suspensions without affecting the integrity of the protein [15]. Following, homogenized samples which contain soluble and precipitated rhBMP-2 were also subjected to bioactivity measurements (see below). For analyzing the soluble fraction of 
rhBMP-2, samples were centrifuged for $15 \mathrm{~min}$ at $17.000 \mathrm{xg}$ and the protein concentration in the supernatant measured as described above. A calibration curve was determined for each buffer using bovine serum albumin (BSA, \#23209, Thermo Fisher Scientific, USA) as standard. All experiments were carried out at least in triplicates.

\section{Effect of ionic strength and presence of heparin on rhBMP-2 precipitation}

To analyze the effect of the ionic strength on rhBMP-2 precipitation experiments were carried out in transparent pureGrade 96 well plates (BRAND, Germany) using the following stock solutions: $500 \mathrm{mM}$ acetate (pH 4.5), $200 \mathrm{mM}$ oxalate (pH 4.5) and $200 \mathrm{mM} \mathrm{NaCl}$. Addition of the stock solutions occurred in the following order: i) $20 \mu \mathrm{l}$ of acetate stock solution, ii) appropriate volumes of oxalate and $\mathrm{NaCl}$ stock solutions and iii) $\mathrm{ddH}_{2} \mathrm{O}$ to reach a volume of $190 \mu \mathrm{l}$ in each well. Finally, $10 \mu \mathrm{l}$ of rhBMP-2 stock solution $(1 \mathrm{mg} / \mathrm{ml})$ were added to each well and the plates allowed incubating at $8^{\circ} \mathrm{C}$ overnight. Precipitation was analyzed by light scattering analysis. All analyses were carried out at least in triplicate. The ionic strength in the solution was calculated as follows:

$$
I=0.5 \sum_{i=1}^{n} c_{i} z_{i}^{2}
$$

with $c$ as the concentration and $z$ as the charge of each ionic component $i$.

The effect of sequential addition of divalent anion (oxalate) and heparin (sodium salt, molar mass approx. $20.000 \mathrm{~g} / \mathrm{mol}$, Carl Roth, Germany, stock solution: $16 \mathrm{mg} / \mathrm{ml}$ ) on the solubility of rhBMP-2 was also tested in acetate buffer at pH 4.5 using a similar experimental setup as described above. Experiments were carried out as follows: addition of rhBMP-2 into oxalatecontaining acetate buffer at $\mathrm{pH} 4.5$, incubation for $1 \mathrm{~h}$ at RT and then addition of heparin (molar ratio of heparin to rhBMP-2 monomer $=5$ ) or addition of rhBMP-2 to heparincontaining acetate buffer at $\mathrm{pH} 4.5$ (molar ratio of heparin to rhBMP-2 monomer $=5$ ), incubation for $1 \mathrm{~h}$ at $\mathrm{RT}$ and then addition of oxalate. Incubation was continued at $8^{\circ} \mathrm{C}$ overnight. All experiments were carried out at least in triplicate. 


\section{Light scattering analysis for precipitation studies}

Precipitation of rhBMP-2 in transparent pureGrade 96 well plates was analyzed by light scattering analyses using a Multiskan GO spectrophotometer (Thermo Fisher Scientific, USA). Prior to measurement, the 96 well plate was shaken for 10 seconds at medium speed and the absorbance at $340 \mathrm{~nm}$ was measured.

\section{Determination of rhBMP-2 precipitate size by dynamic light scattering (DLS)}

The size of rhBMP-2 precipitates was determined using Litesizer ${ }^{\mathrm{TM}} 500$ (Anton-Paar, Austria). rhBMP-2 containing solutions were transferred into polystyrene disposable semimicro cuvettes (BRAND, Germany) and particle scattering was detected using a fixed scattering angle of $90^{\circ}$. The temperature was set to $25^{\circ} \mathrm{C}$. Affiliated DLS data were evaluated with the Kalliope ${ }^{\mathrm{TM}}$ software (Anton-Paar, Austria). Mean of derived size distributions were calculated from at least triplicates.

\section{Analysis of rhBMP-2 precipitates by fluorescence microscopy and image analysis} rhBMP-2 was diluted from a $500 \mu \mathrm{g} / \mathrm{ml}$ stock solution (50 mM MES, pH 5) into $50 \mathrm{mM}$ MES (pH 5), $50 \mathrm{mM}$ MOPS (pH 7) and $50 \mathrm{mM}$ TRIS ( $\mathrm{pH}$ 8) to a final concentration of $25 \mu \mathrm{g} / \mathrm{ml}$ and incubated overnight at $8^{\circ} \mathrm{C}$. Afterwards, samples were stained by adding $1 \mu \mathrm{M}$ Nile Red as described previously [25] and subsequently homogenized by vortexing for 1 - 2 seconds (MS2, IKA, Germany) at mid speed (1400 rpm). $3 \mu$ of stained samples were transferred to a microscope slide (VWR, USA) and visualized using a BX 41 microscope (Olympus, Japan) equipped with a mercury lamp using the Olympus U-MWG filter (EX: 510-500 nm, BS: 570 nm, EM: LP 590). Pictures were taken using the SC30 camera (Olympus, Japan) and the cellSens software (Olympus, Japan). Pictures were further processed using the software ImageJ [26]. The color channels were divided and the red color channel inverted to obtain black stained precipitates on a white background. The image analysis of the precipitate size distribution was carried out as described previously [25]. Briefly, the pictures were thresholded and analyzed by the "Analyze Particles" function of ImageJ using the Feret's diameter for size determination. 


\section{$\underline{\text { Thermal shift assay for thermal stability measurements }}$}

Thermal shift assays were performed to analyze temperature-induced unfolding of rhBMP-2 in different buffers. rhBMP-2 was concentrated by ultrafiltration (Amicon $10 \mathrm{kDa}$, Merck Millipore, USA) to $1 \mathrm{mg} / \mathrm{ml}$ in $50 \mathrm{mM}$ MES ( $\mathrm{pH}$ 5). The resulting rhBMP-2 stock solution was diluted 1:20 into different buffers as described above and incubated at $8^{\circ} \mathrm{C}$ overnight. Samples were mixed afterwards by vortexing for 1 - 2 seconds (MS2, IKA, Germany) at mid speed $(1400 \mathrm{rpm})$ to resuspend (potential) precipitates and $22.5 \mu \mathrm{l}$ per well were added into a 96 well PCR plate already containing $2.5 \mu \mathrm{l}$ per well of a $200 \times$ SYPRO Orange stock solution (obtained by 1:25 dilution with water of the $5000 \times$ SYPRO Orange Protein Gel Stain, Sigma-Aldrich, Germany). The 96 well PCR plate was sealed by a transparent sealing foil (Sarstedt, Germany) and vortexed to mix sample and dye. Prior to analysis the 96 well PCR plate was centrifuged at low speed to sediment droplets of the sample/dye mixture. All samples were analyzed in triplicates in 96 well plates using an iQ5 Real time PCR (Biorad, USA) and the fluorescence monitored using a 545-585 nm cut-off filter. The temperature was raised stepwise from $10^{\circ} \mathrm{C}$ (soluble rhBMP-2) or $30^{\circ} \mathrm{C}$ (aggregated/precipitated rhBMP-2) to $100^{\circ} \mathrm{C}$ by $1^{\circ} \mathrm{C}$ per 45 seconds. The melting (unfolding) temperature $\left(T_{m}\right)$ was determined from the inflection point of the fluorescence peak as described previously [27].

Incubation of rhBMP-2 in different buffers supplemented with chaotropic denaturants and sodium chloride

rhBMP-2 (1 mg/ml in MES, pH 5) was diluted 1:20 into 50 mM MES (pH 5), 50 mM malonate $(\mathrm{pH} 5)$ and $50 \mathrm{mM}$ TRIS buffer $(\mathrm{pH} 8)$ with different concentrations of denaturant $(0-6 \mathrm{M}$ urea or $0-5 \mathrm{M} \mathrm{Gdn}-\mathrm{HCl})$ or salt $(0-3 \mathrm{M} \mathrm{NaCl})$. All samples were incubated overnight $(\sim 16$ h) at $8^{\circ} \mathrm{C}$.

Thermal shift analysis: Afterwards, aliquots of $22.5 \mu \mathrm{l}$ were mixed with $2.5 \mu \mathrm{l}$ of $100 \times$ SYPRO Orange (MES pH 5, TRIS pH 8) and 50 x SYPRO Orange (malonate $\mathrm{pH}$ 5) and subjected to thermal shift analysis. All analyses were carried out at least in triplicate. The thermal shift and data analysis were performed as described above. Intrinsic tryptophane fluorescence: In 
addition, the intrinsic fluorescence of sample aliquots incubated overnight $(\sim 16 \mathrm{~h})$ at $8^{\circ} \mathrm{C}$ in a black pureGrade 96 well plate (BRAND, Germany) with a final volume of $200 \mu \mathrm{l}$ per sample was measured in a F7000 fluorescence spectrophometer (Hitachi, Japan) at room temperature using an excitation wavelength of $280 \mathrm{~nm}$ and emission wavelengths of 330 and $350 \mathrm{~nm}$. The excitation and emission slits were set to $10 \mathrm{~nm}$ and the fluorescence at $350 \mathrm{~nm}$ was divided by the fluorescence at $330 \mathrm{~nm}$ (F350/F330). Light scattering analyses: Prior to light scattering analyses, potential aggregates in samples were resuspended using a multichannel pipette (Eppendorf, Germany) and subsequently $180 \mu \mathrm{l}$ per sample were transferred to a transparent pureGrade 96 well plate (BRAND, Germany) and light scattering analyses carried out as described before.

\section{Bioactivity measurements}

The BMP Responsive Element Luciferase (BRE-Luc) assay was conducted essentially as described previously [28] using a mouse muscle satellite cell line $\mathrm{C} 2 \mathrm{C} 12$ that was stably transfected with the BRE-firefly luciferase reporter plasmid containing an inhibitor of the differentiation promotor-luciferase construct from Korchinsky et al. [29]. For assaying rhBMP2 activity, cells were seeded at a density of 6,500 cells/well in 96 well-plates using standard growth medium (DMEM F0445 (Biochrom, Germany), $10 \%$ FBS South American Origin (Invitrogen), $4 \mathrm{mM}$ glutamine (Biochrom, Germany), $1 \%$ penicillin/streptomycin (Biochrom, Germany), $200 \mu \mathrm{l} /$ well). After four hours, the medium was changed to serum-free growth medium without G418 (100 $\mu$ l/well) and cells were allowed to incubate overnight. Subsequently, rhBMP-2 containing samples (positive control in $50 \mathrm{mM}$ MES buffer pH 5.0 and test samples) and negative control samples (BSA) were added to a final concentration of $100 \mathrm{ng} / \mathrm{ml}$ protein and incubation continued for $24 \mathrm{~h}$. Afterwards, cells were washed with phosphate buffered saline and lysed for 5 min with $100 \mu$ Steady-Glo luciferase reagent (Promega, USA). Subsequently, luciferase measurements were performed with sensitivity being set to $135 \mathrm{RLU} / \mathrm{sec}$ and $1 \mathrm{~s}$ integration time (Synergy 2, Biotek, USA). All analyses 
were carried out from samples prepared at least in triplicate and normalized to rhBMP-2 in 50 mM MES, pH 5 (100 ng/ml, relative light units set to 1$)$.

\section{Three-week stability at different temperatures}

rhBMP-2 was diluted from a $1 \mathrm{mg} / \mathrm{ml}$ stock solution (50 mM MES, pH 5) into $50 \mathrm{mM}$ MES (pH 5), $50 \mathrm{mM}$ malonate (pH 5) and $50 \mathrm{mM}$ TRIS (pH 8) to a final concentration of $50 \mu \mathrm{g} / \mathrm{ml}$ and incubated at $5^{\circ} \mathrm{C}$, room temperature (RT, approx. $\left.20^{\circ} \mathrm{C}\right)$ and $37^{\circ} \mathrm{C}$ for various time points $(0-$ 23 days). Each time point corresponds to $3-6$ independent samples which were prepared at different days for incubation at different temperatures ( $0-23$ days). All samples were prepared under sterile conditions and incubated in sealed tubes to prevent evaporation. After 23 days all samples were homogenized by pipetting and analyzed together on a single day for thermal stability, light scattering and bioactivity as described above. The time zero sample was analyzed approx. $3 \mathrm{~h}$ after dilution into the respective buffer at indicated temperature. Data were normalized to the time zero sample of rhBMP-2 in $50 \mathrm{mM} \mathrm{MES,} \mathrm{pH} 5(50 \mathrm{ng} / \mathrm{ml}$, relative light units set to 1 ).

\section{Analysis overview}

All analytical tools and buffer conditions applied for studies on the properties of soluble and precipitated rhBMP-2 are summarized In Table 1.

\section{$\underline{\text { rhBMP-2 structure visualization }}$}

Three-dimensional structure data of rhBMP-2 were obtained from the RCSB Protein Data Bank (PDB ID 3BMP). The pH dependent charges were calculated using ProteinPrepare [30] and visualized using Chimera [31]. 


\section{Results and discussion}

\section{pH-dependent solubility of rhBMP-2 in different buffers}

For pH-dependent solubility studies, rhBMP-2 in $50 \mathrm{mM}$ MES buffer ( $\mathrm{pH}$ 5) was diluted into different buffers covering a $\mathrm{pH}$ range from $\mathrm{pH} 2-\mathrm{pH} 11$. The amount of soluble rhBMP-2 was determined after overnight incubation as the amount of rhBMP-2 that remained in the supernatant after 15 minutes centrifugation at $17.000 \times \mathrm{g}$ (Fig. 1). The analysis revealed a dependency of rhBMP-2 solubility on the $\mathrm{pH}$ but also on the type of buffer used. In the range of $\mathrm{pH} 2-\mathrm{pH} 5$ rhBMP-2 remained soluble in all buffers tested (Fig. 1A). With increasing pH the solubility of rhBMP-2 decreased. Above $\mathrm{pH} 7$ rhBMP-2 formed precipitates in all buffers investigated and no soluble protein was detectable except at $\mathrm{pH} 11$ at which a part of rhBMP-2 remained soluble. Within the $\mathrm{pH}$ range of $\mathrm{pH} 6-\mathrm{pH} 7$ rhBMP-2 solubility was strongly dependent on the nature of the buffer. In this $\mathrm{pH}$ range it was insoluble in phosphate buffer whereas its solubility was higher in MES and even more in MOPS buffer (Fig. 1A).

\section{Presence of multivalent anions decreases the solubility of rhBMP-2}

We further addressed the question why rhBMP-2 was insoluble in phosphate buffer at $\mathrm{pH} 6$ and above but still remained soluble in MOPS buffer at $\mathrm{pH}$ 7. It was hypothesized that the presence of divalent anions may enhance the aggregation propensity of rhBMP-2. E. coli derived rhBMP-2 has an isoelectric point around $\mathrm{pl} 8.5$ [3] and thus is positively charged below pH 8.5 (see also Fig. 1B). MOPS and MES buffers are zwitterionic buffers, but phosphate buffer at $\mathrm{pH} 6-\mathrm{pH} 8$ also contains divalent anions $\left(\mathrm{HPO}_{4}{ }^{2-}\right)$ which may crosslink the positively charged rhBMP-2 dimers (Fig. 2) this way contributing to an increased aggregation propensity of the protein. Moreover, the positive charges are clustered on the surface of rhBMP-2 facilitating the divalent anion (or $\mathrm{HPO}_{4}{ }^{2-}$ ) mediated crosslinking (Fig. $2 \mathrm{C}$ ). To test this hypothesis we searched for compounds containing divalent anions at even lower $\mathrm{pH}$ than phosphate $(\mathrm{pKa} 2=7.2)$. Suitable candidates were identified as malonate $(\mathrm{pKa} 2=$ 5.7) and oxalate $(\mathrm{pKa} 2=4.2)$. The results of these experiments clearly supported the hypothesis that the presence of divalent anions enhances the aggregation propensity of 
rhBMP-2 (Fig. 2A). rhBMP-2 only remained soluble in malonate buffer at a pH below approx. $\mathrm{pH}$ 4.5. The solubility was even further decreased in oxalate buffer in which soluble rhBMP-2 was only detectable at a $\mathrm{pH}$ below $\mathrm{pH}$ 3.5. To exclude a simple ionic strength effect being responsible for the enhanced precipitation of rhBMP-2 in the presence of divalent anions, experiments were also carried out in $50 \mathrm{mM}$ acetate buffer $(\mathrm{pH}$ 4.5) supplemented with increasing concentrations of $\mathrm{NaCl}$ or oxalate, $\mathrm{pH} 4.5$ (Fig. 2B). These analyses revealed that oxalate caused precipitation of rhBMP-2 at considerably lower ionic strength compared to $\mathrm{NaCl}$ (in $50 \mathrm{mM}$ acetate buffer, $\mathrm{pH}$ 4.5) supporting the conclusion that precipitation by divalent anions is a specific and not only an ionic strength effect (see also Supplementary material).

\section{$\underline{\text { Heparin modifies divalent anion mediated precipitation of rhBMP-2 }}$}

We further addressed the question if the presence of heparin modifies divalent anion mediated precipitation of rhBMP-2. Heparin is a negatively charged polysaccharide which binds specifically to certain cytokines, including BMP-2, through electrostatic but also other non-covalent interactions to modify their function [22,32]. Interference of heparin with divalent anion mediated precipitation was tested by addition of rhBMP-2 to acetate buffer at $\mathrm{pH} 4.5$ supplemented with either heparin or oxalate. After one hour incubation, oxalate was added to rhBMP-2 preincubated with heparin and heparin was added to rhBMP-2 preincubated with oxalate (Fig. 3A). The analyses revealed that heparin was able to reduce precipitation of rhBMP-2 when it was present prior to the addition of oxalate. However, heparin was not able to solubilize oxalate provoked rhBMP-2 precipitates. On the contrary, addition of heparin to rhBMP-2 precipitates in oxalate supplemented acetate buffer, $\mathrm{pH} 4.5$ intensified rhBMP-2 precipitation and/or increased the size of precipitates. In the absence of oxalate, Heparin did not lead to significant precipitation (Fig. 3B). These data indicate that binding of divalent anions occurs presumably in the vicinity of the heparin binding site of rhBMP-2.

\section{Size of soluble rhBMP-2 and rhBMP-2 precipitates in different buffers}


The $\mathrm{pH}$-dependent size of soluble and precipitated rhBMP-2 in different buffers was determined using dynamic light scattering (DLS) and fluorescent image analysis. DLS data were analyzed as both intensity percentage versus size and volume percentage versus size (Fig. 4). Samples containing soluble rhBMP-2 displayed on average a similar intensity size distribution in the range of $10-300 \mathrm{~nm}$ with distinct peaks at $\sim 18$ and $\sim 100 \mathrm{~nm}$ (Fig. 4A). The first peak at $\sim 18 \mathrm{~nm}$ can be assigned to the soluble disulfide-bonded rhBMP-2 dimer. The size of the rhBMP-2 dimer corresponds to $3.5 \times 3.5 \times 7 \mathrm{~nm}^{3}$ using X-ray crystallographic data [2]. The size should be larger in solution when the surrounding hydrate shell contributes to the spatial requirement of the molecule (hydrodynamic size). The second peak at $\sim 100 \mathrm{~nm}$ can be assigned to small soluble rhBMP-2 nanoparticles. The height or area of both peaks cannot be used for particle quantification as light scattering intensity increases proportional to the power of six with the particle diameter and thus larger particles appear overrepresented [33]. For estimating the relative level of different size populations the volume distribution is more suitable. This analysis revealed for the smaller particles a peak shift to a maximum at -11 $\mathrm{nm}$ being more compatible with the size of the dimer as determined by X-ray crystallography. Moreover, the larger sized population $(\sim 100 \mathrm{~nm})$ nearly disappeared using the volume percentage versus size analysis illustrating that these samples mainly contained soluble dimeric rhBMP-2. Protein particles were also determined with Nile red staining and subsequent fluorescence microscopy. These analyses also revealed the presence of small soluble particles in samples containing soluble rhBMP-2 comparable to the size determined by DLS measurements (Fig. 4A). Samples containing partially soluble rhBMP-2 in MOPS (pH 7) and CAPS buffer ( $\mathrm{pH} \mathrm{11)} \mathrm{did} \mathrm{not} \mathrm{contain} \mathrm{soluble} \mathrm{dimeric} \mathrm{molecules} \mathrm{but} \mathrm{at} \mathrm{least} \mathrm{partly}$ soluble aggregates with a distinct size distribution ranging from 50 to $300 \mathrm{~nm}$ (peak at $\sim 115$ $\mathrm{nm}$ ) and 90 to $500 \mathrm{~nm}$ (peak at $\sim 190 \mathrm{~nm}$ ), respectively (Fig. 4B). The fluorescence microscopic analysis of e.g. rhBMP-2 in MOPS buffer $(\mathrm{pH} 7)$ confirmed the presence of soluble nanoparticular aggregates with the corresponding size distribution. Analysis of samples containing exclusively precipitated rhBMP-2 $(\mathrm{pH} 7-11)$ revealed size distributions 
larger than the upper detection limit of DLS (> $1 \mu \mathrm{m}$, data not shown). For these samples, a representative fluorescence microscopic image analysis of rhBMP-2 in TRIS buffer (pH 8.5) is shown, revealing particles with a mean Feret's diameter of $4.5 \mu \mathrm{m}$ (Fig. 4C).

\section{Thermal stability of soluble rhBMP-2 and rhBMP-2 precipitates incubated in different buffers} Thermal shift assays using SYPRO Orange were conducted to assess the thermal stability of soluble rhBMP-2 and rhBMP-2 precipitates at different $\mathrm{pH}$ and in different buffers (Fig. 5). Examples of temperature-induced denaturation of soluble rhBMP-2 at acidic (citrate, $\mathrm{pH} 3$ ), precipitated rhBMP-2 close to neutral (phosphate, $\mathrm{pH}$ 6) and partly soluble rhBMP-2 at alkaline conditions (CAPS buffer, $\mathrm{pH} 11$ ) are shown (Fig. 5A). The data show that rhBMP-2 is less stable - although more soluble - at extreme $\mathrm{pH}$ compared to the precipitated protein close to neutral $\mathrm{pH}$. Denaturation of rhBMP-2 as indicated by the inflection point occurs at $41^{\circ} \mathrm{C}$ at $\mathrm{pH} 3$ and at even lower temperature $\left(32^{\circ} \mathrm{C}\right)$ at $\mathrm{pH} 11$. Precipitated rhBMP-2 in phosphate buffer at $\mathrm{pH} 6$ is rather stable, denaturation of the protein does not occur before $62^{\circ} \mathrm{C}$. Interestingly, the initial fluorescence, namely the binding of SYPRO orange to rhBMP-2 at low temperature, is rather high prior to denaturation in phosphate buffer $(\mathrm{pH} 7.5)$ presumably due to enhanced surface hydrophobicity of the precipitated protein (Fig. 5A). The analysis of the $\mathrm{pH}$-dependent thermal stability of rhBMP-2 revealed that the protein exhibited the highest stability in the $\mathrm{pH}$-range of $\mathrm{pH} 5$ to $\mathrm{pH} 9$ reaching the maximum stability in phosphate buffer at $\mathrm{pH} 6$ (Fig. 5B). The thermal stability is lowest at the $\mathrm{pH}$ extremes where repulsive charges within the molecule contribute to facilitated unfolding and denaturation. A comparison of the thermal stability of rhBMP-2 clearly revealed that precipitated rhBMP-2 (e.g. in malonate buffer at $\mathrm{pH}$ 4.5) exhibited a higher stability compared to soluble rhBMP-2 at the same $\mathrm{pH}$ (e.g. in acetate buffer at $\mathrm{pH}$ 4.5). The denaturation temperature increased from $53^{\circ} \mathrm{C}$ in acetate buffer to $63^{\circ} \mathrm{C}$ in malonate buffer at $\mathrm{pH} 4.5$ (Fig. 5B).

\section{$\underline{\text { Resolubilisation of rhBMP-2 precipitates in MES buffer ( } \mathrm{pH} 5)}$}

The thermal shift analysis revealed that rhBMP-2 retained its hydrophobic core when precipitated indicating resolvability when exposed to conditions disfavoring precipitation. To 
test for resolubilisation, rhBMP-2 precipitates from different buffers (malonate, $\mathrm{pH} 5$; MES, pH 7; phosphate, pH 7; MOPS, pH 7.5; TRIS, pH 8; CHES, pH 9 and CAPS, $\mathrm{pH}$ 10.5) were pelleted by centrifugation and resuspended in the same volume of MES buffer ( $\mathrm{pH} 5)$. Quantification of the soluble protein after overnight incubation revealed that 85 to $98 \%$ of the rhBMP-2 precipitates were resolubilized in MES buffer $(\mathrm{pH} \mathrm{5)}$ (see also Supplementary material for details).

Stability of soluble rhBMP-2 and rhBMP-2 precipitates towards chaotropic denaturants

Guanidinium hydrochloride $(\mathrm{Gdn}-\mathrm{HCl})$ and urea are the most common chaotropes employed for studies on protein (un)folding but also for denaturing solubilisation of bacterial inclusion bodies with $\mathrm{Gdn}-\mathrm{HCl}$ being an ionic and stronger denaturant than non-ionic urea. Moreover, $\mathrm{Gdn}-\mathrm{HCl}$ and urea have been used for extraction and purification of bovine BMP-2 from bones [34].

The stability of soluble rhBMP-2 and rhBMP-2 precipitates towards urea and Gdn-HCl was determined after incubation of rhBMP-2 for $16 \mathrm{~h}$ in MES ( $\mathrm{pH} 5$, soluble rhBMP-2), malonate ( $\mathrm{pH} 5$, rhBMP-2 precipitate) and TRIS buffer ( $\mathrm{pH} 8$, rhBMP-2 precipitate) in a series of increasing chaotrope concentrations with subsequent analysis of the (thermal) stability and solubility (Fig. 6). These analyses corroborated above findings that precipitated rhBMP-2 is more thermostable than soluble rhBMP-2 (Fig. 6A). Thermal unfolding of (precipitated) rhBMP-2 in malonate $(\mathrm{pH} 5)$ and TRIS buffer $(\mathrm{pH} 8)$ occurred at approx. $8^{\circ} \mathrm{C}$ and $5^{\circ} \mathrm{C}$ higher temperature, respectively, compared to soluble rhBMP-2 in MES buffer $(\mathrm{pH} 5)$ at all urea concentrations investigated. A generally higher thermostability of rhBMP-2 in the buffer containing the divalent malonate anion compared to MES buffer at the same $\mathrm{pH}$ was only found when the non-ionic denaturant urea was employed. In $\mathrm{Gdn}-\mathrm{HCl}$ supplemented buffers rhBMP-2 was only more thermostable in malonate buffer compared to MES buffer of the same $\mathrm{pH}$ at lower $\mathrm{Gdn}-\mathrm{HCl}$ concentrations (up to approx. $2 \mathrm{M}$ ) suggesting that the ionic denaturant $\mathrm{Gdn}-\mathrm{HCl}$ finally outcompetes the stabilizing effect of the multivalent buffer anion at higher denaturant concentrations. Interestingly, rhBMP-2 (precipitates) in TRIS buffer (pH 
8, close to the $\mathrm{pl}$ of rhBMP-2) were stabilized through low concentrations of $\mathrm{Gdn}-\mathrm{HCl}(0-1 \mathrm{M}$ $\mathrm{Gdn}-\mathrm{HCl}$ with the maximum thermostability at around $0.5 \mathrm{M} \mathrm{Gdn}-\mathrm{HCl}$, Fig. $6 \mathrm{~A}$ ) suggesting a stabilizing effect of $\mathrm{Gdn}-\mathrm{HCl}$ through electrostatic interactions at low concentrations which was not found with the non-ionic chaotrope urea. In this line, the refolding yield of rhBMP-2 from $E$. coli derived solubilised inclusion bodies was also enhanced in the presence of 0 - 1 M Gdn- $\mathrm{HCl}$ (refolding at $\mathrm{pH} 8.5$, [9]). Stabilization of proteins by low concentrations of $\mathrm{GdnHCl}$ is not unknown and has been assigned to unspecific binding of $\mathrm{GdnH}^{+}$to the protein leading to stiffening and shrinkage of the hydrodynamic volume $[35,36]$ but also to more specific binding of the $\mathrm{GdnH}^{+}$cation to the protein $[37,38]$.

The dissolution of rhBMP-2 precipitates by denaturants differed markedly in non-ionic urea and ionic $\mathrm{Gdn}-\mathrm{HCl}$ solutions (Fig. 6B). rhBMP-2 precipitates in malonate $(\mathrm{pH} 5)$ and TRIS buffer $(\mathrm{pH}$ 8) were already dissolved at $0.5 \mathrm{M} \mathrm{Gdn}-\mathrm{HCl}$ without significant differences while rhBMP-2 precipitates in TRIS $(\mathrm{pH}$ 8) exhibited a pronounced resistance towards ureamediated dissolution compared to the precipitates in malonate buffer $(\mathrm{pH} 5)$. Around $4 \mathrm{M}$ urea was required to dissolve the precipitates in TRIS $(\mathrm{pH} 8)$ whereas only $2 \mathrm{M}$ urea was sufficient for dissolution of rhBMP-2 precipitates in malonate buffer $(\mathrm{pH}$ ). Compared to the other buffers, rhBMP-2 (precipitates) in TRIS buffer $(\mathrm{pH}$ 8) also displayed a significantly higher resistance towards urea-mediated unfolding as indicated by the shift in the change of the protein fluorescence maximum from 330 to $350 \mathrm{~nm}$ to higher urea concentrations (approx. $4 \mathrm{M}$ urea, Fig. 6C). In $\mathrm{Gdn}-\mathrm{HCl}$ supplemented buffers the change in the tryptophane fluorescence was similar for rhBMP-2 in all buffers investigated indicating a similar midpoint of unfolding at approximately $2 \mathrm{M} \mathrm{Gdn-HCl}$ (Fig. 6C).

\section{Effect of $\mathrm{NaCl}$ addition on stability and solubility of rhBMP-2 in different buffers}

The different behavior of rhBMP-2 towards increasing concentrations of urea and $\mathrm{Gdn}-\mathrm{HCl}$ suggested that electrostatic interactions play an important role in stabilizing the protein and in stabilizing protein-protein interactions. These findings prompted us to study the effect of $\mathrm{NaCl}$ addition on the thermal stability and solubility of rhBMP-2 in the tested buffer systems. 
The thermal stability of rhBMP-2 increased upon $\mathrm{NaCl}$ addition in all buffer systems investigated (Fig. 7A). Thus, $\mathrm{NaCl}$ acts as a stabilizing salt on rhBMP-2. In this line, studies on the refolding kinetics of rhBMP-2 revealed that addition of $\mathrm{NaCl}$ to the refolding buffer accelerated rhBMP-2 refolding and also the final refolding yield [39].

The impact of $\mathrm{NaCl}$ addition on rhBMP-2 solubility was more complex (Fig. 7B). For rhBMP-2 precipitates in malonate $(\mathrm{pH} 5)$ and TRIS buffer $(\mathrm{pH} 8)$ a "salting-in" was first observed at $\mathrm{NaCl}$ concentrations up to approx. $0.8 \mathrm{M} \mathrm{NaCl}$ followed by "salting-out" at higher $\mathrm{NaCl}$ concentrations. Surprisingly, addition of $\mathrm{NaCl}$ to soluble rhBMP-2 in MES buffer (pH 5) caused precipitation of rhBMP-2 at concentrations of already $80 \mathrm{mM} \mathrm{NaCl}$ and higher. At $\mathrm{NaCl}$ concentrations of $0.3 \mathrm{M}$ and above rhBMP-2 precipitates in MES buffer $(\mathrm{pH} 5)$ displayed a similar "salting-in" and "salting-out" profile as determined for the precipitates in malonate $(\mathrm{pH} 5)$ and TRIS buffer $(\mathrm{pH}$ 8). Precipitation of rhBMP-2 at low concentrations of $\mathrm{NaCl}$ in MES buffer ( $\mathrm{pH} 5$ ) might be caused by binding of the chloride anion to rhBMP-2 (positively charged at $\mathrm{pH} 5$ ) leading to charge neutralisation and enhanced protein-protein interactions which lead to protein precipitation. Salting-in and -out interactions are known to control protein behaviour at higher salt concentrations whereas at lower salt concentration the main effect of increasing salt concentration leads to charge neutralisation through ion binding to oppositely charged groups of the protein this way decreasing the electrostatic barrier to precipitation [40].

\section{Bioactivity of soluble rhBMP-2 and rhBMP-2 precipitates incubated in different buffers}

The bioactivity of soluble rhBMP-2 and rhBMP-2 precipitates incubated in buffers of different $\mathrm{pH}$ and composition was analyzed using the sensitive BRE-Luc assay (Fig. 8). rhBMP-2 was incubated overnight in different buffers and aliquots taken after carefully resuspending potential precipitates were subjected to bioactivity measurements. These analyses clearly revealed that precipitation of rhBMP-2 did not compromise the bioactivity of the protein. All rhBMP-2 samples obtained from these different buffers revealed high biological activity although a tendency towards lower activity was observed for samples incubated at extreme 
$\mathrm{pH}$. High standard deviations of activity measurements are presumably due to aliquotation from rhBMP-2 suspensions as formed precipitates tend to settle to the bottom.

Three-weeks stability of soluble rhBMP-2 and rhBMP-2 precipitates incubated in different $\underline{\text { buffers }}$

Moreover, the three-weeks stability of soluble rhBMP-2 and rhBMP-2 precipitates was assessed at $5^{\circ} \mathrm{C}$, room temperature and $37^{\circ} \mathrm{C}$ in different buffers (MES, $\mathrm{pH} 5$; malonate, $\mathrm{pH}$ 5 and TRIS, $\mathrm{pH}$ 8). Thermal stability measurements corroborated the higher thermal stability of rhBMP-2 precipitates compared to the soluble version of the protein (Fig. 9A). During incubation at $37^{\circ} \mathrm{C}$ the unfolding temperature of rhBMP-2 (precipitates) in malonate (pH 5) and TRIS ( $\mathrm{pH}$ 8) even increased with time and, surprisingly, rhBMP-2 remained bioactive even after three-weeks incubation at $37^{\circ} \mathrm{C}$ (Fig. 9). Even more surprising, rhBMP-2 incubated at $37^{\circ} \mathrm{C}$ in malonate buffer $(\mathrm{pH} 5)$ revealed an apparent increase in bioactivity with time. On the other hand, rhBMP-2 precipitates in TRIS buffer $(\mathrm{pH} 8)$ displayed an apparent loss of half their initial bioactivity after dilution into the incubation buffer. We do not have any clear-cut explanation for these findings but assume that aging of precipitates (e.g. reshuffling of disulfide bonds at higher $\mathrm{pH}$ ) in different buffers (e.g. malonate, $\mathrm{pH} 5$ versus TRIS, $\mathrm{pH}$ 8) may lead to conformational changes connected to a loss in bioactivity or to a difference in the (resolubilization) behaviour of the rhBMP-2 precipitates under bioassay conditions (24 $\mathrm{h}$ incubation together with $\mathrm{C} 2 \mathrm{C} 12$ cells in serum free growth medium).

Temporary incubation of bioactive rhBMP-2 in chaotropic denaturants does not destroy bioactivity

Thermal shift assays as well as measurements of the intrinsic tryptophan fluorescence revealed that incubation of bioactive soluble rhBMP-2 and bioactive rhBMP-2 precipitates overnight in $6 \mathrm{M}$ urea and $4 \mathrm{M} \mathrm{Gdn}-\mathrm{HCl}$ was leading to unfolding of the protein as indicated by the loss of the hydrophobic core and solvent exposure of tryptophan. However, dilution of urea and $\mathrm{Gdn}-\mathrm{HCl}$ unfolded, but formerly correctly folded and disulfide-bonded rhBMP-2 into $50 \mathrm{mM}$ MES buffer ( $\mathrm{pH} \mathrm{5,} \mathrm{1:10} \mathrm{dilution,} \mathrm{final} \mathrm{concentration} 5 \mu \mathrm{g} / \mathrm{ml}$ ) and subsequent activity 
analysis did not show any loss of bioactivity (Fig. 8B). These findings indicate that rhBMP-2, once properly folded and disulfide bonded, can overcome denaturant-induced unfolding presumably due to the stabilizing nature of the cystine knots.

\section{Discrimination of bioactive rhBMP-2 (precipitates) from misfolded rhBMP-2 (aggregates)}

Refolding of rhBMP-2 into the correctly folded disulfide-bonded bioactive dimer containing properly formed cystine knots in each monomer is a very slow process [39]. During renaturation of rhBMP-2 under appropriate redox conditions after reducing and chaotropic solubilisation of $E$. coli derived inclusion bodies (see Materials and Methods) rhBMP-2 partly aggregates, in particular, when renaturation occurs at high protein concentrations [9]. These aggregates are mainly formed at the beginning of the renaturation procedure and they are not resolvable in MES buffer ( $\mathrm{pH} 5)$. These aggregates are also not bioactive and - when exposed to thermal unfolding in the presence SYPRO orange - do not show the characteristic fluorescence peak found with bioactive rhBMP-2 precipitates (Fig. 8B, and data not shown). In this line, similar peak-less fluorescence profiles were obtained when dimeric rhBMP-2 was directly recovered by mild extraction and not through refolding from $E$. coli derived inclusion bodies [10]. These disulfide bonded dimers were soluble in MES buffer ( $\mathrm{pH}$ 5), but did not possess correctly formed cystine knots and did not show any bioactivity [10]. Also, heat-sterilized rhBMP-2 did not show the characteristic fluorescence peak during thermal unfolding concomitant to a loss in bioactivity (see Fig. 9). Thus, the absence of the characteristic fluorescence peak during thermal unfolding of rhBMP-2 either in soluble or aggregated form is a clear indication for the absence of properly folded and bioactive rhBMP2 showing that misfolding and the absence of proper disulfide bonds, e.g. proper cystine knots, in rhBMP-2 are connected to an unstructured conformation and the absence of a defined hydrophobic core. 


\section{Conclusions}

rhBMP-2 is known as a very stable protein with a high tendency to form aggregates. Usually, attempts are undertaken to prevent aggregation of proteins in particular when they are intended for usage as biopharmaceuticals [41]. In case of rhBMP-2 it might be conceivable to also consider the usage of the protein in precipitated form as the bioactivity - inducing bone formation - should be locally clearly restricted to prevent harmful side effects. Our analysis revealed that $E$. coli derived rhBMP-2 precipitates are not only bioactive but are also more stable compared to the soluble dimeric molecules. Thus, the E. coli derived rhBMP-2 deserves more attention as a potential drug for biopharmaceutical applications in bone repair. Its neglect in comparison to the cell culture derived product appears to be a result of its higher tendency towards precipitation [11,42] and poor knowledge on its unusual properties. On the other hand, special care must be taken to distinguish active E. coli derived rhBMP-2 precipitates generated by controlled precipitation from inactive aggregates generated through wrong protein handling. Our findings should be useful to design improved delivery systems based on better knowledge on rhBMP-2 properties requiring lower amounts of protein in clinical applications. Also, our results should be helpful to solve analytical problems connected to the poor solubility and the unusual properties of this protein.

\section{Acknowledgements}

The authors gratefully acknowledge funding through the Forschungsgruppe "Gradierte Implantate" FOR2180 and the Exzellenzcluster "Rebirth" EXC62, both Deutsche Forschungsgemeinschaft (DFG), and excellent technical assistance by Anika Hamm (bioactivity measurements), Graded Implants and Regenerative Strategies. We also want to thank the reviewers for their careful and critical reading which helped a lot to improve the manuscript. 


\section{Abbreviations}

BRE-LUC

$\mathrm{CHO}$

DLS

E. coli

$\mathrm{Gdn}-\mathrm{HCl}$

nRFU

$\mathrm{nRLU}$

pl

rhBMP-2

RLU

TGF- $\beta$

$\mathrm{Tm}$
BMP Responsive Element Luciferase

Chinese Hamster Ovary

Dynamic Light Scattering

Escherichia coli

Guanidine hydrochloride

normalized Relative Fluorescence Units

normalized Relative Light Units

Isoelectric point

Recombinant human bone morphogenetic protein 2

Relative Light Units

Transforming growth factor $\beta$

Denaturation (melting) temperature 
References

1. Celeste AJ, lannazzi JA, Taylor RC, Hewick RM, Rosen V, Wang EA, Wozney JM. Identification of transforming growth factor beta family members present in boneinductive protein purified from bovine bone. Proc Natl Acad Sci U S A. 1990;87:9843-7.

2. Scheufler $C$, Sebald $W$, Hülsmeyer M. Crystal structure of human bone morphogenetic protein-2 at 2.7 Å resolution. J Mol Biol. 1999;287:103-15.

3. Uludag H, D'Augusta D, Golden J, Li J, Timony G, Riedel R, Wozney JM. Implantation of recombinant human bone morphogenetic proteins with biomaterial carriers: A correlation between protein pharmacokinetics and osteoinduction in the rat ectopic model. J Biomed Mater Res. 2000;50:227-38.

4. McKay WF, Peckham SM, Badura JM. A comprehensive clinical review of recombinant human bone morphogenetic protein-2 (INFUSE Bone Graft). Int Orthop. 2007;31:72934.

5. Granjeiro JM, Oliveira RC, Bustos-Valenzuela JC, Sogayar MC, Taga R. Bone morphogenetic proteins: from structure to clinical use. Braz J Med Biol Res. 2005;38:1463-73.

6. El Bialy I, Jiskoot W, Reza NM. Formulation, delivery and stability of bone morphogenetic proteins for effective bone regeneration. Pharm Res. 2017;34:1152-70.

7. Wozney JM, Rosen V, Celeste AJ, Mitsock LM, Whitters MJ, Kriz RW, Hewik RM, Wang EA. Novel regulators of bone formation: molecular clones and activities. Science. 1988;242:1528-34.

8. Walsh G. Biopharmaceutical benchmarks 2010. Nat Biotechnol. 2010;28:917-24.

9. Vallejo LF, Rinas U. Optimized procedure for renaturation of recombinant human bone morphogenetic protein-2 at high protein concentration. Biotechnol Bioeng. 2004;85:601-9.

10. Quaas B, Burmeister L, Li Z, Nimtz M, Hoffmann A, Rinas U. Properties of dimeric, disulfide-linked rhBMP-2 recovered from $E$. coli derived inclusion bodies by mild extraction or chaotropic solubilisation and subsequent refolding. Process Biochem. 2018;67:80-7.

11. van de Watering FC, van den Beucken JJ, van der Woning SP, Briest A, Eek A, Qureshi H, Winnubst L, Boerman OC, Jansen JA. Non-glycosylated BMP-2 can induce ectopic bone formation at lower concentrations compared to glycosylated BMP-2. J Control Release. 2012;159:69-77.

12. Nakashima M, Reddi AH. The application of bone morphogenetic proteins to dental tissue engineering. Nat Biotechnol. 2003;21:1025-32.

13. Katagiri T, Yamaguchi A, Ikeda T, Yoshiki S, Wozney JM, Rosen V, Wang EA, Tanaka $\mathrm{H}$, Omura S, Suda T. The non-osteogenic mouse pluripotent cell line, C3H10T1/2, is induced to differentiate into osteoblastic cells by recombinant human bone morphogenetic protein-2. Biochem Biophys Res Commun. 1990;172:295-9. 
14. Kisiel M, Ventura M, Oommen OP, George A, Walboomers XF, Hilborn J, Varghese OP. Critical assessment of rhBMP-2 mediated bone induction: an in vitro and in vivo evaluation. J Control Release. 2012;162:646-53.

15. Schwartz D, Sofia S, Friess W. Integrity and stability studies of precipitated rhBMP-2 microparticles with a focus on ATR-FTIR measurements. Eur J Pharm Biopharm. 2006;63:241-8.

16. Sofia SJ, Schwartz D, Friess W. Formulation comprising bioactive agents and method of using them. US Patent 7,897,174 B2. 2011.

17. Sampath TK, Reddi AH. Dissociative extraction and reconstitution of extracellular matrix components involved in local bone differentiation. Proc Natl Acad Sci USA. 1981;78:7599-603.

18. Luca L, Capelle MA, Machaidze G, Arvinte T, Jordan O, Gurny R. Physical instability, aggregation and conformational changes of recombinant human bone morphogenetic protein-2 (rhBMP-2). Int J Pharm. 2010;391:48-54.

19. Abbatiello SE, Porter TJ. Anion-mediated precipitation of recombinant human bone morphogenetic protein (rhBMP-2) is dependent upon the Heparin binding N-terminal region. Poster presented at the Protein Society Meeting, Boston MA, July 13-16. 1997.

20. Gilde F, Maniti O, Guillot R, Mano JF, Logeart-Avramoglou D, Sailhan F, Picart C. Secondary structure of rhBMP-2 in a protective biopolymeric carrier material. Biomacromolecules. 2012;13:3620-6.

21. Yano K, Hoshino M, Ohta Y, Manaka T, Naka Y, Imai Y, Sebald W, Takaoka K. Osteoinductive capacity and heat stability of recombinant human bone morphogenetic protein-2 produced by Escherichia coli and dimerized by biochemical processing. J Bone Miner Metab. 2009;27:355-63.

22. Ruppert R, Hoffmann E, Sebald W. Human bone morphogenetic protein 2 contains a heparin-binding site which modifies its biological activity. Eur J Biochem. 1996;237:295302.

23. Vallejo LF, Brokelmann M, Marten S, Trappe S, Cabrera-Crespo J, Hoffmann A, Gross $\mathrm{G}$, Weich HA, Rinas U. Renaturation and purification of bone morphogenetic protein-2 produced as inclusion bodies in high-cell-density cultures of recombinant Escherichia coli. J Biotechnol. 2002;94:185-94.

24. Georgiou CD, Grintzalis K, Zervoudakis G, Papapostolou I. Mechanism of Coomassie brilliant blue G-250 binding to proteins: a hydrophobic assay for nanogram quantities of proteins. Anal Bioanal Chem. 2008;391:391-403.

25. Demeule B, Gurny R, Arvinte T. Detection and characterization of protein aggregates by fluorescence microscopy. Int J Pharm. 2007;329:37-45.

26. Schindelin J, Rueden CT, Hiner MC, Eliceiri KW. The ImageJ ecosystem: An open platform for biomedical image analysis. Mol Reprod Dev. 2015;82:518-29.

27. Boivin S, Kozak S, Meijers R. Optimization of protein purification and characterization using Thermofluor screens. Protein Expr Purif. 2013;91:192-206. 
28. Lorenz C, Hoffmann A, Gross G, Windhagen H, Dellinger P, Mohwald K, Dempwolf W, Menzel $\mathrm{H}$. Coating of titanium implant materials with thin polymeric films for binding the signaling protein BMP2. Macromol Biosci. 2011;11:234-44.

29. Korchynskyi O, ten Dijke P. Identification and functional characterization of distinct critically important bone morphogenetic protein-specific response elements in the Id1 promoter. J Biol Chem. 2002;277:4883-91.

30. Martinez-Rosell G, Giorgino T, De FG. PlayMolecule ProteinPrepare: A Web application for protein preparation for molecular dynamics simulations. J Chem Inf Model. 2017;57:1511-6.

31. Pettersen EF, Goddard TD, Huang CC, Couch GS, Greenblatt DM, Meng EC, Ferrin TE. UCSF Chimera - a visualization system for exploratory research and analysis. J Comput Chem. 2004;25:1605-12.

32. Bolten S, Rinas U, Scheper T. Heparin: Role in protein purification and substitution with animal-component free material. Appl Microbiol Biotechnol. 2018;102:8647-60.

33. Zhou C, Qi W, Lewis EN, Carpenter JF. Characterization of sizes of aggregates of insulin analogs and the conformations of the constituent protein molecules: a concomitant dynamic light scattering and raman spectroscopy study. J Pharm Sci. 2016;105:551-8.

34. Urist MR, Huo YK, Brownell AG, Hohl WM, Buyske J, Lietze A, Tempst P, Hunkapiller $M$, DeLange RJ. Purification of bovine bone morphogenetic protein by hydroxyapatite chromatography. Proc Natl Acad Sci U S A. 1984;81:371-5.

35. Rao MT, Bhuyan AK, Venu K, Sastry VS. Nonlinear effect of GdnHCl on hydration dynamics of proteins: a $1 \mathrm{H}$ magnetic relaxation dispersion study. J Phys Chem B. 2009;113:6994-7002.

36. Kumar R, Bhuyan AK. Entropic stabilization of myoglobin by subdenaturing concentrations of guanidine hydrochloride. J Biol Inorg Chem. 2009;14:11-21.

37. Sole M, Brandt W, Arnold U. Striking stabilization of Rana catesbeiana ribonuclease 3 by guanidine hydrochloride. FEBS Lett. 2013;587:737-42.

38. Mayr LM, Schmid FX. Stabilization of a protein by guanidinium chloride. Biochemistry. 1993;32:7994-8.

39. Vallejo LF, Rinas U. Folding and dimerization kinetics of bone morphogenetic protein-2, a member of the transforming growth factor- $\beta$ family. FEBS J. 2013;280:83-92.

40. Roberts D, Keeling R, Tracka M, van der Walle CF, Uddin S, Warwicker J, Curtis R. Specific ion and buffer effects on protein-protein interactions of a monoclonal antibody. Mol Pharm. 2015;12:179-93.

41. Roberts CJ. Therapeutic protein aggregation: mechanisms, design, and control. Trends Biotechnol. 2014;32:372-80.

42. Schmoekel H, Schense JC, Weber FE, Gratz KW, Gnagi D, Muller R, Hubbell JA. Bone healing in the rat and dog with nonglycosylated BMP-2 demonstrating low solubility in fibrin matrices. J Orthop Res. 2004;22:376-81. 


\section{Figure captions}

Figure 1: $\mathrm{pH}$ and buffer dependent solubility of rhBMP-2. (A) Left: rhBMP-2 in $50 \mathrm{mM} M E S$ $(\mathrm{pH} 5)$ was diluted into indicated buffers to a final concentration of $25 \mu \mathrm{g} / \mathrm{ml}$ and the amount of soluble rhBMP-2 determined after overnight incubation. The data are presented as mean $\pm S D, n=3-5$. (B) Charge distribution on the surface of the rhBMP-2 dimer at different $\mathrm{pH}$; red: positive charge, blue: negative charge, gray: hydrophobic residues, numbers in brackets refer to the percentage of charged amino acids.

Figure 2: Divalent and monovalant anion dependent precipitation of rhBMP-2. (A) Left: As in (Fig. 1A) but diluting into buffers containing the divalent buffer anions malonate, oxalate and phosphate. Data for acetate buffer (monovalent anion) are also included for better comparability. All data are presented as mean $\pm S D, n=3-5$. (B) Precipitation of rhBMP-2 as function of the ionic strength in $50 \mathrm{mM}$ acetate puffer $(\mathrm{pH} \mathrm{4.5)} \mathrm{supplemented} \mathrm{with} \mathrm{increasing}$ concentration of sodium oxalate or sodium chloride. The data are presented as mean $\pm S D$, $\mathrm{n}=3$. (C) Chemical structure of divalent anions and cartoon depicting potential divalent anion mediated aggregation of rhBMP-2; red: positive charge, blue: negative charge (charge distribution at $\mathrm{pH}$ 6), gray: hydrophobic residues. Please note that the angle/view on the rhBMP-2 model is different compared to Fig. 1B for a better visualization of the clustering of positive charges.

Figure 3: Heparin modified precipitation of rhBMP-2 through divalent anions (oxalate) followed by light scatter analysis. (A) rhBMP-2 incubated overnight in acetate buffer $(\mathrm{pH} 4.5)$ supplemented at indicated concentrations of oxalate (circles), incubation of rhBMP-2 in acetate buffer $(\mathrm{pH} 4.5)$ supplemented with Heparin (Heparin/rhBMP-2 monomer molar ratio 5) for one hour followed by addition of oxalate to indicated concentrations and subsequent overnight incubation (diamonds) and incubation of rhBMP-2 in oxalate supplemented acetate 
buffer $(\mathrm{pH} \mathrm{4.5)}$ for one hour followed by addition of Heparin to a final molar ratio of 5 (Heparin/rhBMP-2 monomer) and subsequent overnight incubation (squares). (B) rhBMP-2 incubated overnight in acetate buffer ( $\mathrm{pH}$ 4.5) supplemented with Heparin at indicated Heparin/rhBMP-2 monomer molar ratios. All data are presented as mean $\pm S D, n=3$.

Figure 4: The size distribution of soluble and precipitated rhBMP-2 in different buffers (composition and incubation time as in Fig. 1) was investigated by fluorescence microscopy ( $A$ - C, upper part), DLS measurements ( $A$ and $B$, middle and lower part) and Image analysis (C, middle and lower part). (A) Predominantly soluble rhBMP-2 in different buffers $(\mathrm{pH} 2-\mathrm{pH}$ 6.5), (B) partly soluble rhBMP-2 in MOPS (pH 7) and CAPS ( $\mathrm{pH} 11)$, and (C) Example of precipitated rhBMP-2 in TRIS, $\mathrm{pH}$ 8. Solid lines are averages by mean and error bars correspond to standard deviations. Fluorescence microscopic images show examples in buffers as indicated. The data are presented as mean $\pm S D, n>5$ for $A$ and $B$, while for $C$ the data show a frequency distribution with an interval size of $1000, n=620$ (particle count).

Figure 5: $\mathrm{pH}$ and buffer dependent thermal stability of soluble rhBMP-2 and rhBMP-2 precipitates. (A) Temperature-dependent SYPRO Orange fluorescence of soluble rhBMP-2 at acidic (citrate, $\mathrm{pH} 3$ ), precipitated rhBMP-2 at neutral (phosphate, $\mathrm{pH}$ 6) and partly soluble rhBMP-2 at alkaline conditions (CAPS, pH 11). RFUs in each experiment were normalized setting the highest value to 1 in each experiment (nRFU). (B) $\mathrm{pH}$ and buffer dependent denaturation temperature (melting temperature $\mathrm{T}_{\mathrm{m}}$ ) of soluble rhBMP-2 and rhBMP-2 precipitates. The data are presented as mean $\pm S D, n=3$ (A: shaded area, $B$ : error bars).

Figure 6: Urea (left side) and $\mathrm{Gdn}-\mathrm{HCl}$ (right side) dependent (thermo)stability of rhBMP-2 and dissolution of rhBMP-2 precipitates. (A) Urea and $\mathrm{Gdn}-\mathrm{HCl}$ dependent change in the 
denaturation temperature $\left(T_{m}\right)$ of soluble rhBMP-2 (MES, pH 5) and rhBMP-2 precipitates (malonate, pH 5 and TRIS, pH 8). (B) Urea and Gdn-HCl dependent dissolution of rhBMP-2 precipitates (malonate, $\mathrm{pH} 5$ and TRIS, $\mathrm{pH}$ 8) as determined by light scattering analyses at $340 \mathrm{~nm}$ (with soluble rhBMP-2 in MES ( $\mathrm{pH}$ 5) serving as baseline control). (C) Urea and Gdn- $\mathrm{HCl}$ dependent unfolding of soluble rhBMP-2 (MES, pH 5) and rhBMP-2 precipitates (malonate, $\mathrm{pH} 5$ and TRIS, $\mathrm{pH}$ 8) as determined by the intrinsic tryptophan fluorescence (F350/F330). The data are presented as mean $\pm S D, n=3$.

Figure 7: Effect of $\mathrm{NaCl}$ addition on thermal stability and solubility of rhBMP-2. $\mathrm{NaCl}$ dependent change in the $(A)$ denaturation temperature $\left(T_{m}\right)$ and $(B)$ solubility of rhBMP-2 (soluble rhBMP-2 in MES, $\mathrm{pH} 5$ and rhBMP-2 precipitates in malonate, $\mathrm{pH} 5$ and TRIS, $\mathrm{pH}$ 8). The data are presented as mean $\pm S D, n=3$.

Figure 8: $\mathrm{pH}$ and buffer dependent biological activity of soluble rhBMP-2 and rhBMP-2 precipitates/aggregates. (A) $\mathrm{pH}$ and buffer dependent bioactivity of soluble rhBMP-2 and rhBMP-2 precipitates after incubation in different buffers (incubation as described in Fig. 1). (B) Bioactivity of "denatured" rhBMP-2. Positive: positive control (100 ng/ml rhBMP-2 in 50 $\mathrm{mM}$ MES, $\mathrm{pH}$ 5); Gdn- $\mathrm{HCl}$ and Urea: bioactive rhBMP-2 incubated overnight in $4 \mathrm{M} \mathrm{Gdn-HCl}$ and $6 \mathrm{M}$ urea (both in $50 \mathrm{mM}$ MES, $\mathrm{pH}$ 5), respectively, and analyzed for bioactivity afterwards. Refolding aggregates: rhBMP-2 (misfolded) aggregates recovered by centrifugation from $2 \mathrm{ml}$ refolding mixture, washed with MES ( $\mathrm{pH}$ 5) and resuspended in 100 $\mu \mathrm{l} 50 \mathrm{mM}$ MES (pH 5) and Negative: negative control (BSA in MES, pH 5). RLUs for each experiment were normalized to rhBMP-2 in 50 mM MES, pH 5 as positive control, which was set to $1(n R L U)$. Data points are presented as mean $\pm S D, n=3$. 
Figure 9: Three-week stability of soluble rhBMP-2 and rhBMP-2 precipitates at different temperatures. rhBMP-2 from frozen stocks $(1 \mathrm{mg} / \mathrm{ml}$ in 50mM MES, $\mathrm{pH} 5)$ was diluted into 50 mM MES ( $\mathrm{pH} 5)$, Malonate $(\mathrm{pH} 5)$ and TRIS buffer $\left(\mathrm{pH}\right.$ 8). Solutions were incubated at $5^{\circ} \mathrm{C}$, room temperature (RT) and $37^{\circ} \mathrm{C}$ and (A) thermal stability, (B) solubility and (C) bioactivity of rhBMP-2 in these buffers determined at indicated time points. RLUs for each experiment were normalized to rhBMP-2 in MES, $\mathrm{pH} 5$ as positive control at time zero, which was set to 1 (nRLU). As negative control rhBMP-2 diluted into MES ( $\mathrm{pH} 5)$, malonate $(\mathrm{pH} 5)$ and TRIS buffer $\left(\mathrm{pH}\right.$ 8) was heat sterilized at $120^{\circ} \mathrm{C}$ for $30 \mathrm{~min}$. Negative control samples did not show any characteristic fluorescence peak during thermal unfolding in the presence SYPRO orange (data not included). All data are presented as mean $\pm S D, n=3-6$. 


\section{Tables}

Table 1 rhBMP-2 Characterisation

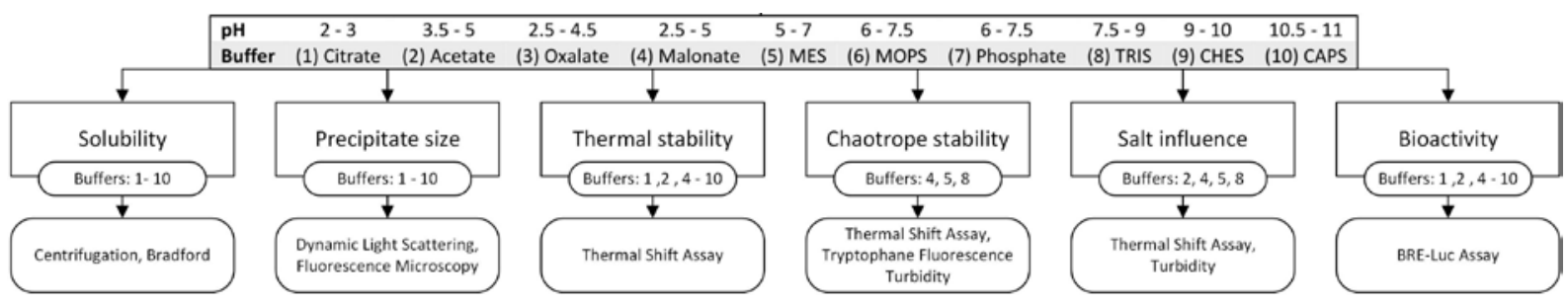


Figures

Figure 1

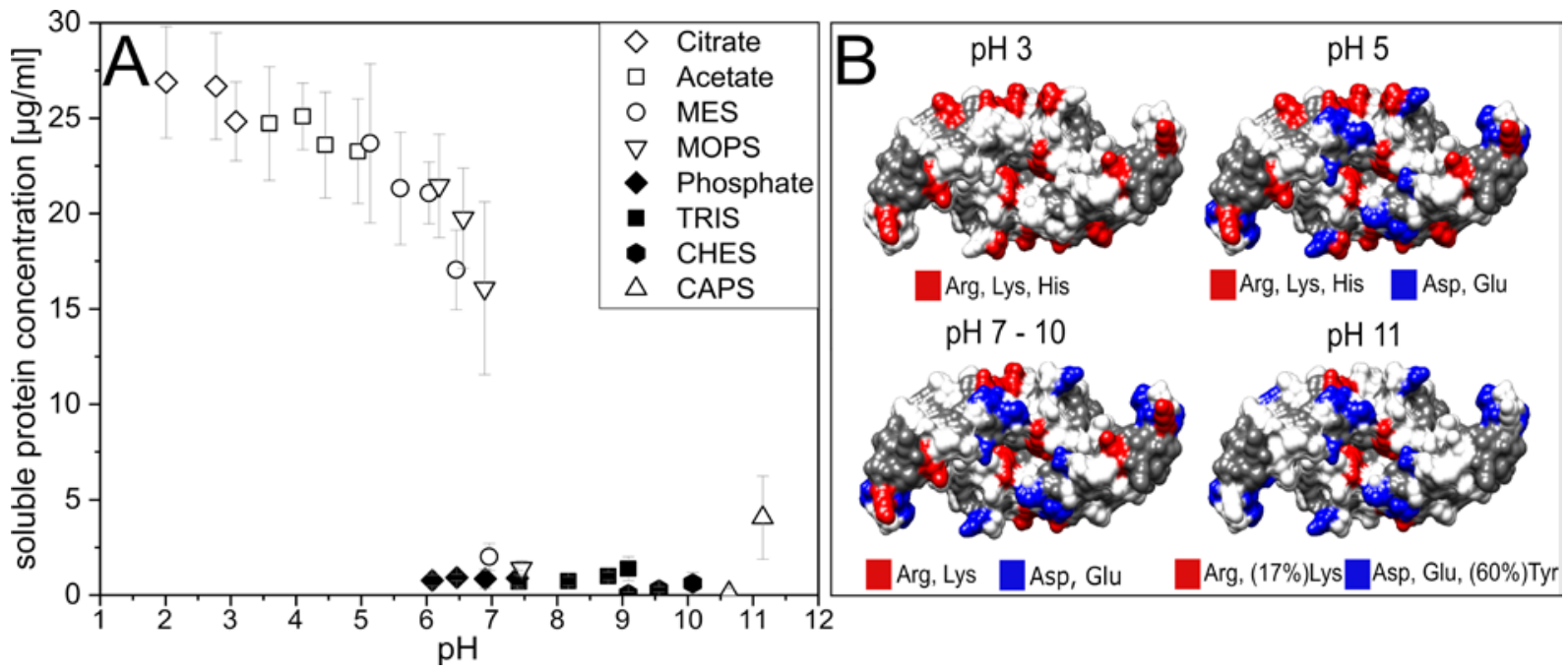

Figure 2
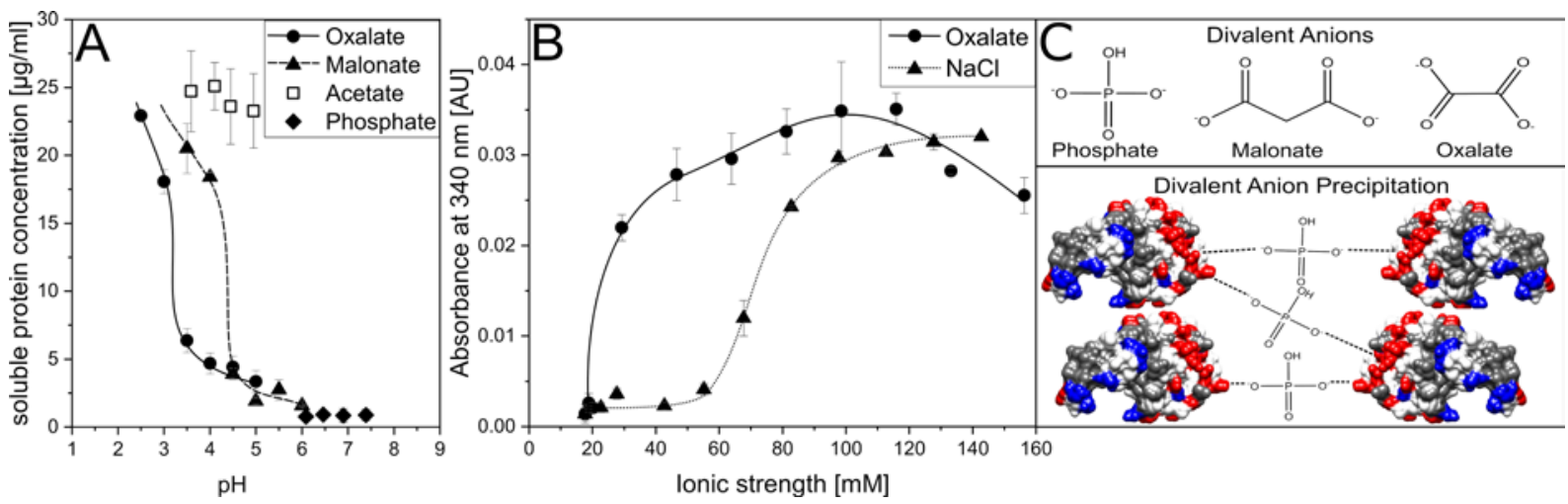
Figure 3
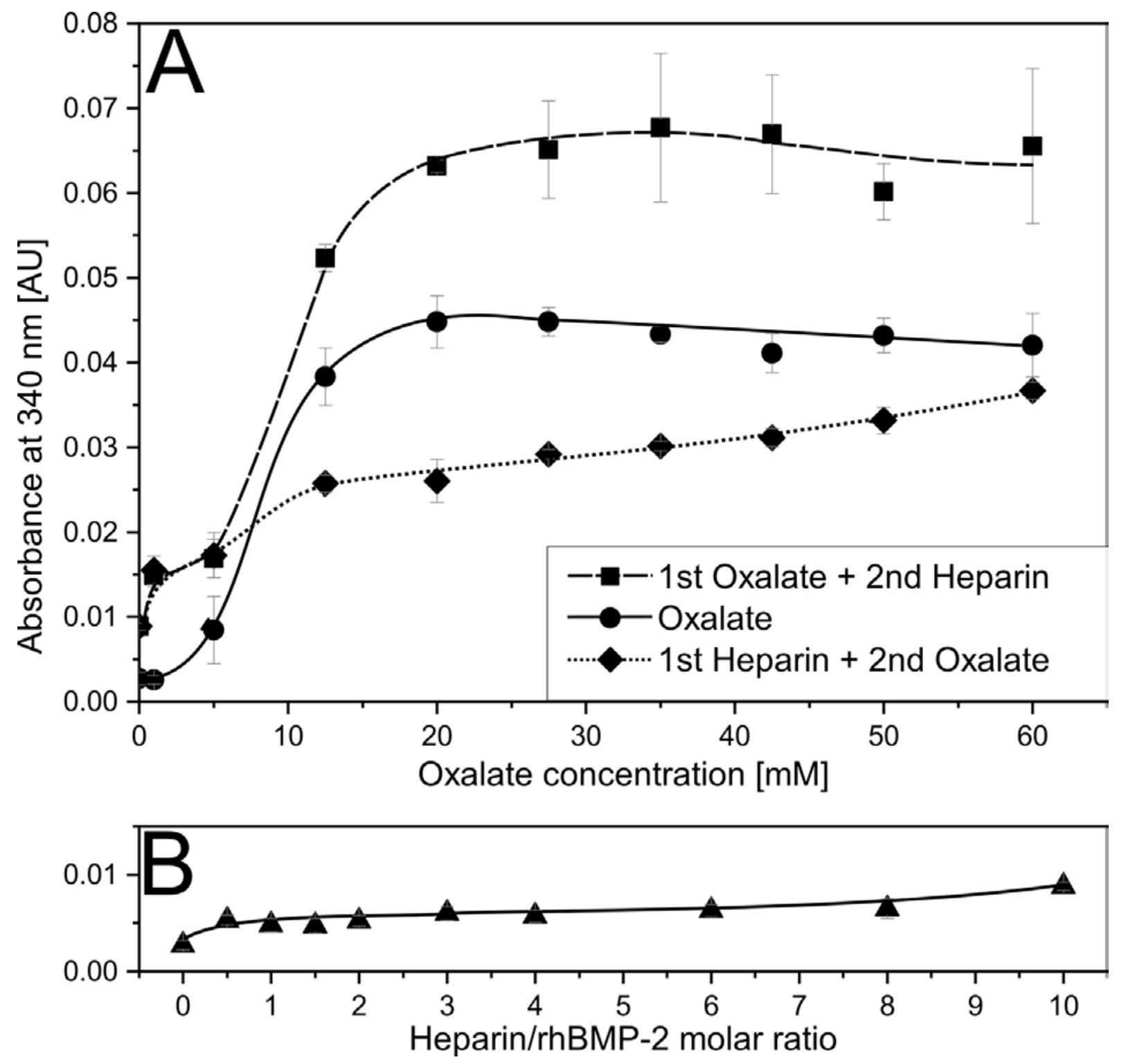
Figure 4

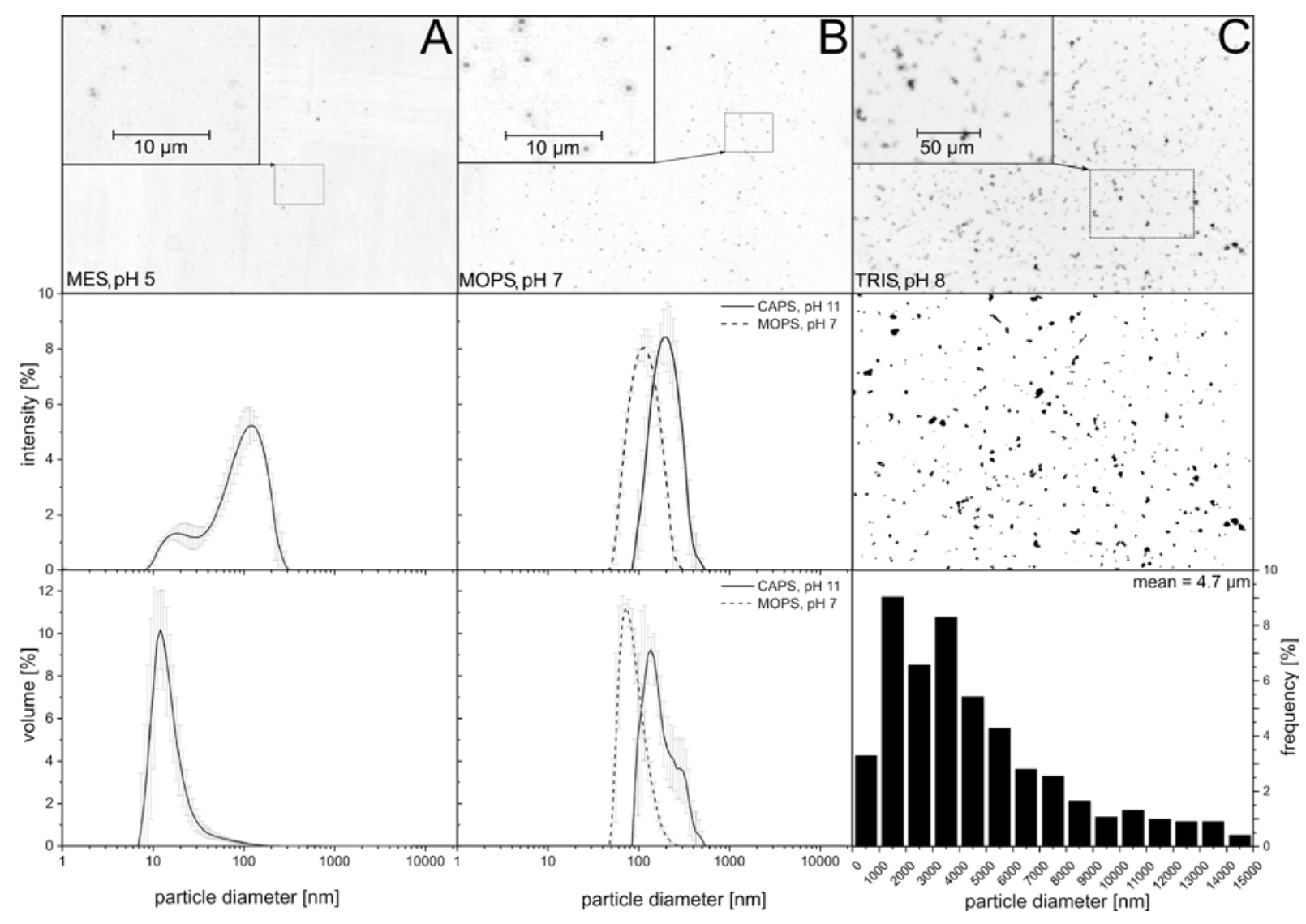

Figure 5
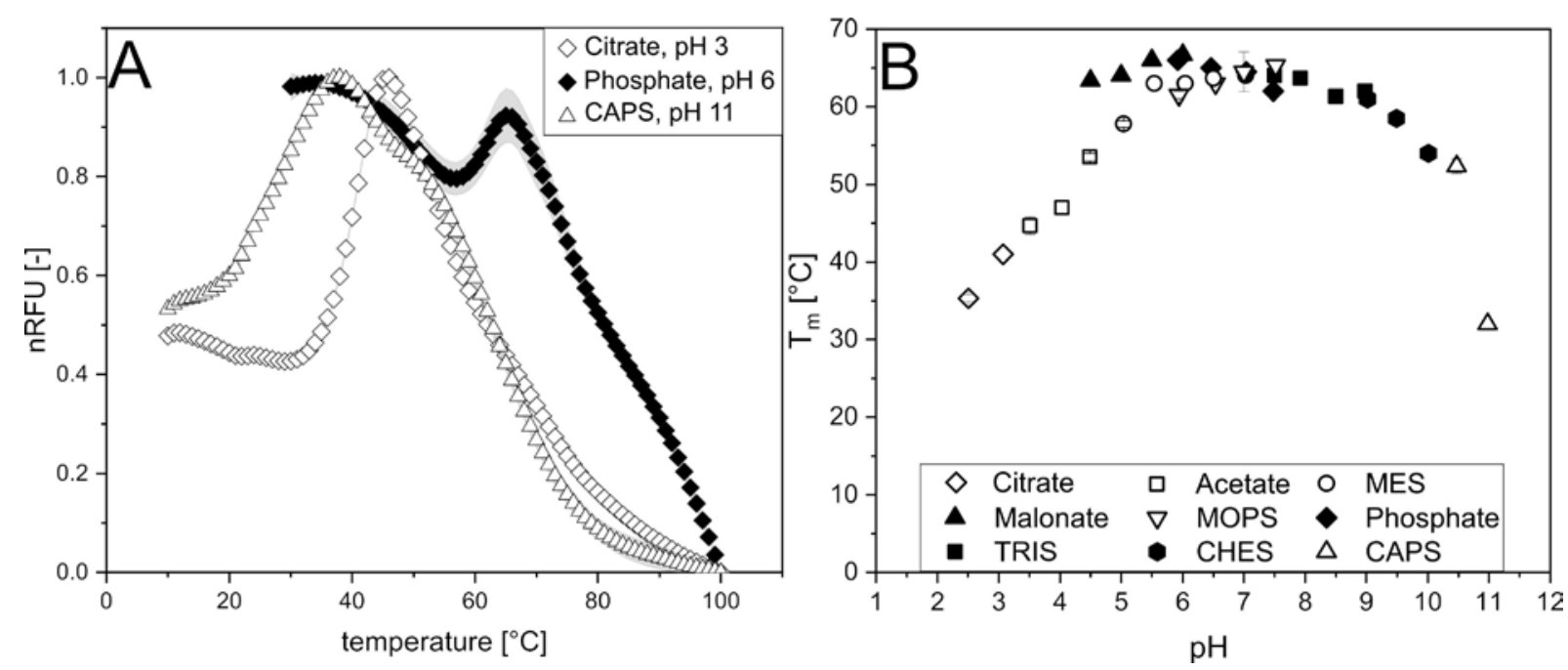
Figure 6

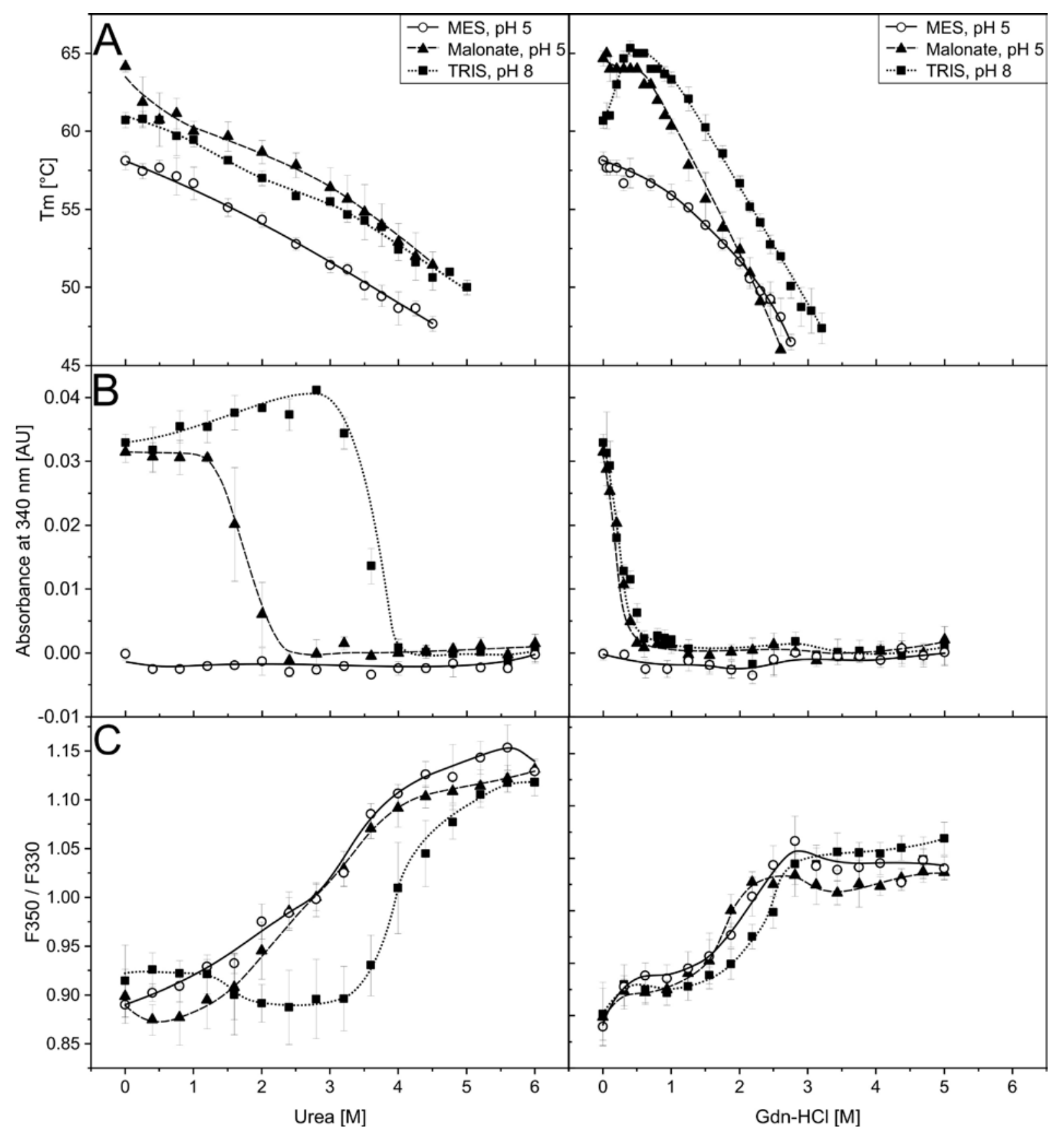


Figure 7

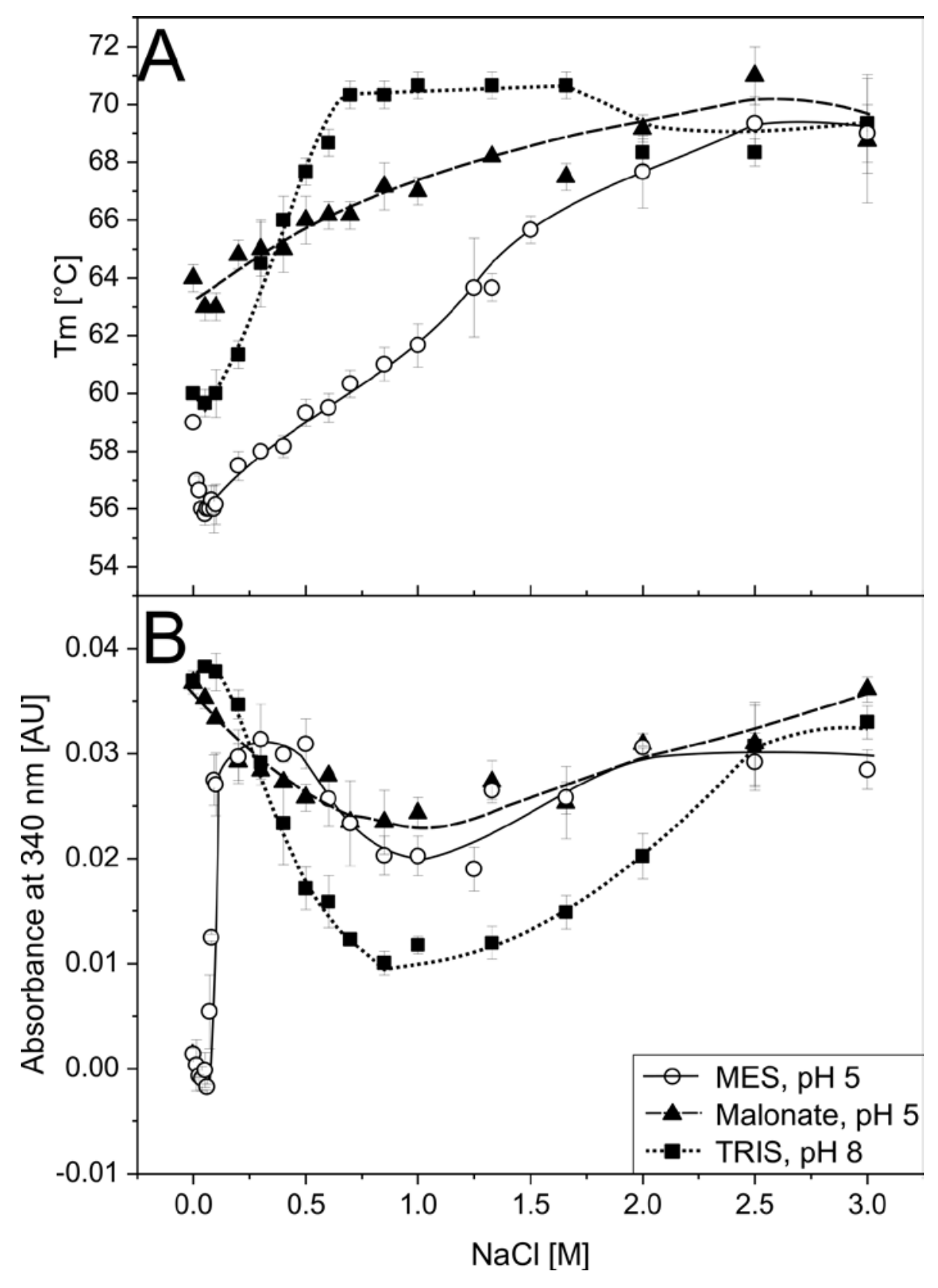


Figure 8
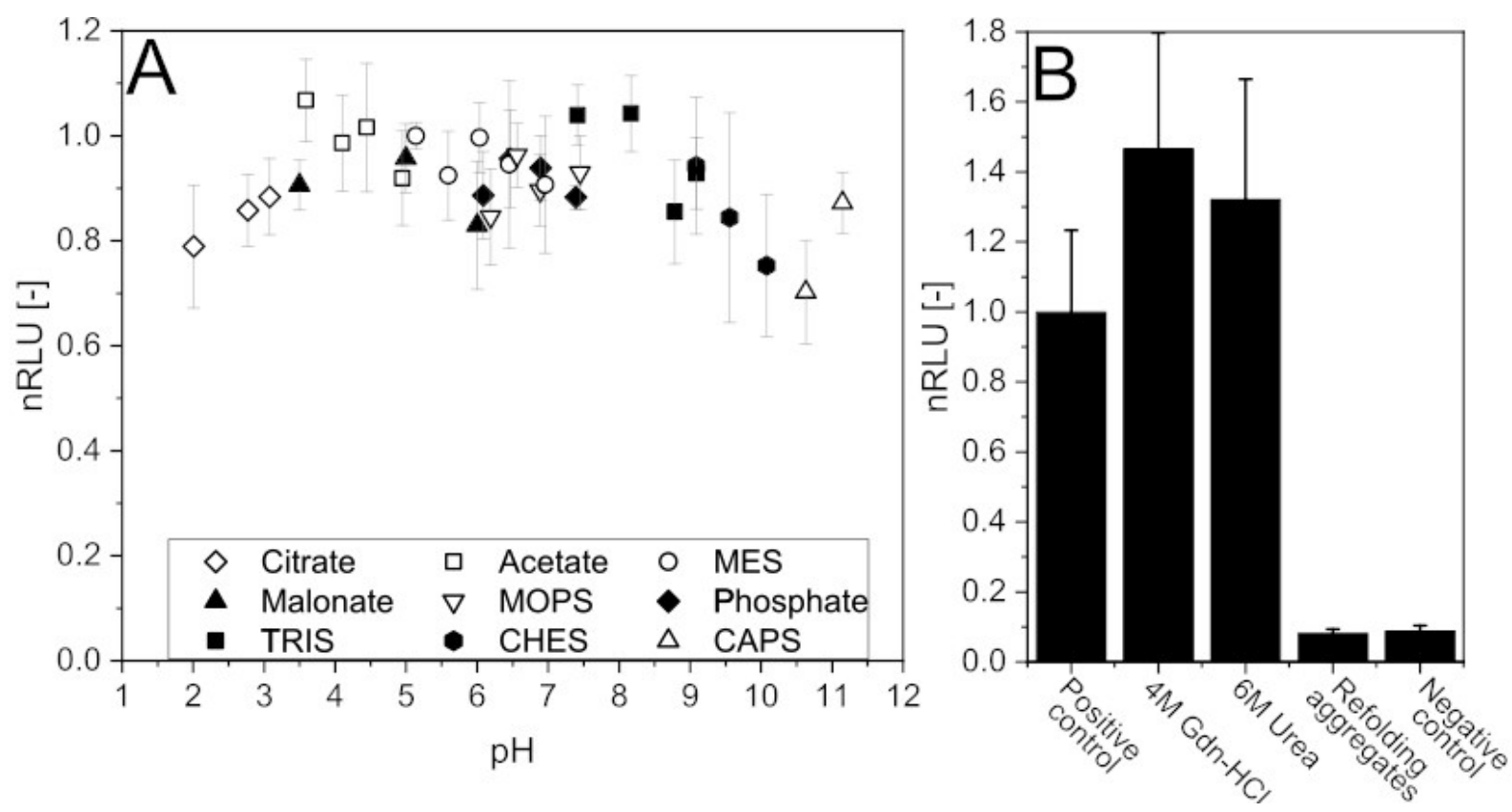

Figure 9

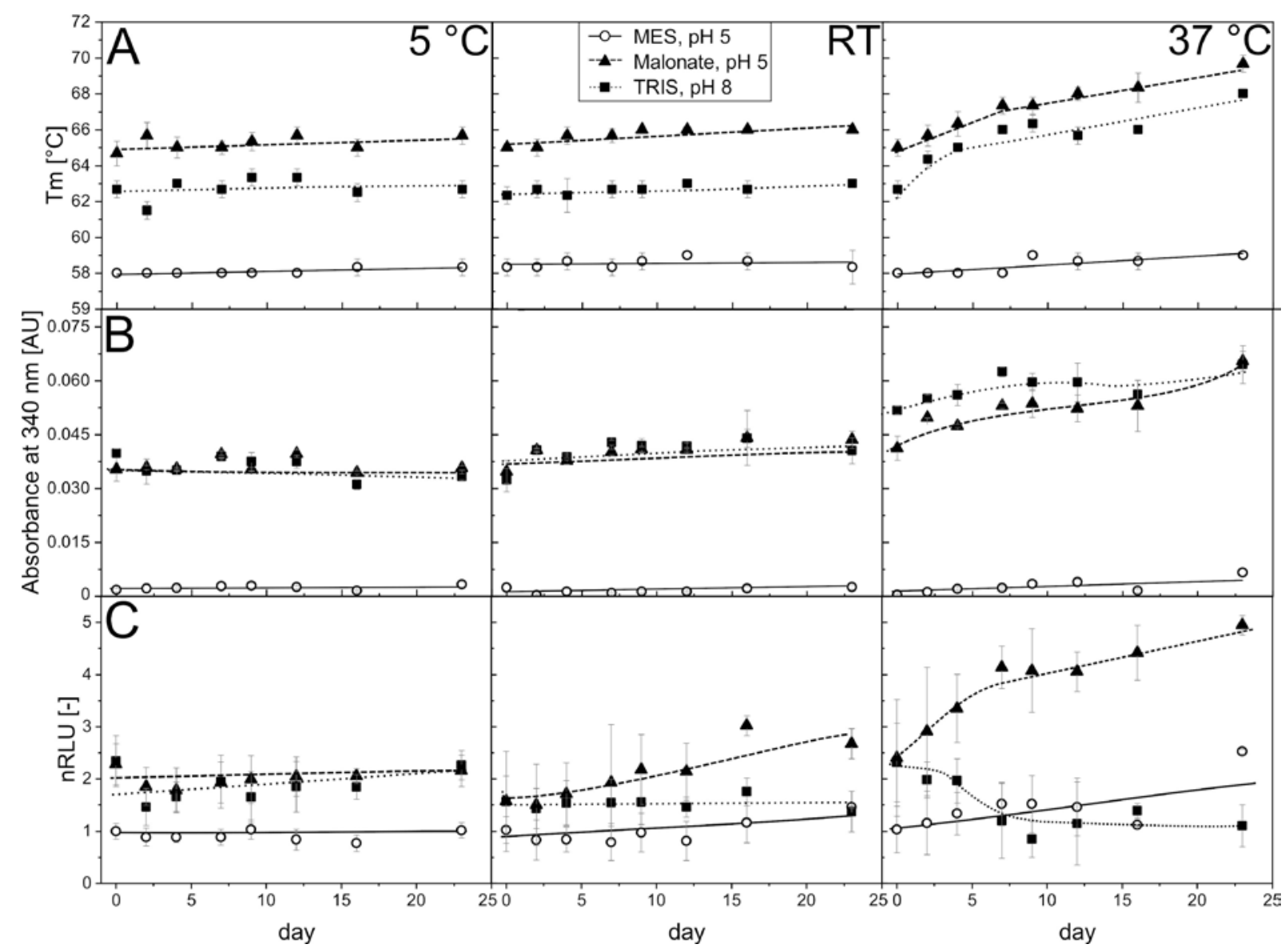

